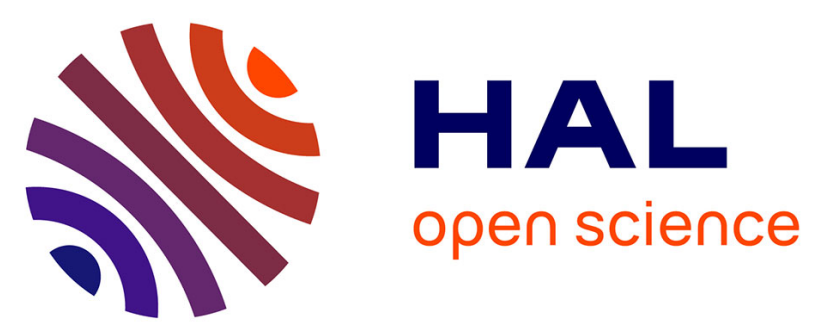

\title{
Environmental control on shell structure and composition of agglutinated foraminifera along a proximal-distal transect in the Marmara Sea
}

Eric Armynot Du Châtelet, Viviane Bout-roumazeilles, Rodolfo Coccioni, Fabrizio Frontalini, François Guillot, Michael A Kaminski, Philippe Recourt, Armelle Riboulleau, Alain Trentesaux, Nicolas Tribovillard, et al.

\section{To cite this version:}

Eric Armynot Du Châtelet, Viviane Bout-roumazeilles, Rodolfo Coccioni, Fabrizio Frontalini, François Guillot, et al.. Environmental control on shell structure and composition of agglutinated foraminifera along a proximal-distal transect in the Marmara Sea. Marine Geology, 2013, 335, pp.114 - 128. 10.1016/j.margeo.2012.10.013 . hal-03280590

\author{
HAL Id: hal-03280590 \\ https://hal.science/hal-03280590
}

Submitted on 26 Jul 2021

HAL is a multi-disciplinary open access archive for the deposit and dissemination of scientific research documents, whether they are published or not. The documents may come from teaching and research institutions in France or abroad, or from public or private research centers.
L'archive ouverte pluridisciplinaire HAL, est destinée au dépôt et à la diffusion de documents scientifiques de niveau recherche, publiés ou non, émanant des établissements d'enseignement et de recherche français ou étrangers, des laboratoires publics ou privés. 


\section{Environmental control on shell structure and composition of agglutinated foraminifera along a proximal-distal transect in the Marmara Sea}

Eric Armynot du Châtelet ${ }^{\mathrm{a}, *}$, Viviane Bout-Roumazeilles ${ }^{\mathrm{a}}$, Rodolfo Coccioni ${ }^{\mathrm{b}}$, Fabrizio Frontalini b, François Guillot ${ }^{a}$, Michael A. Kaminski ${ }^{c, 1}$, Philippe Recourt ${ }^{a}$, Armelle Riboulleau $^{\text {a }}$, Alain Trentesaux ${ }^{\text {a }}$, Nicolas Tribovillard ${ }^{\text {a }}$, Sandra Ventalon ${ }^{\text {a }}$

${ }^{a}$ Université Lille 1, UMR 8217 CNRS Géosystèmes, UFR Sciences de la Terre, Bât SN5, Avenue Paul Langevin, 59655 Villeneuve d'Ascq, France

${ }^{\mathrm{b}}$ Dipartimento di Scienze della Terra, della Vita e dell'Ambiente (DiSTeVA), Università degli Studi di Urbino "Carlo Bo", Campus Scientifico Enrico Mattei, Località Crocicchia, 61029 Urbino, Italy

${ }^{\mathrm{c}}$ Department of Earth Sciences, University College London, Gower Street, London, WCIE 6BT, UK

* Corresponding author. E-mail address: eric.armynot@univ-lille1.fr (E. Armynot du Châtelet).

1 Current address: Earth Sciences Department, King Fahd University of Petroleum \& Minerals, PO Box 701, Dhahran, 31261, Saudi Arabia; and Department of Earth Sciences, UCL, Gower Street, London, WC1E 6BT, UK.

Keywords: Benthic agglutinated foraminifera, Marmara Sea, Geochemistry, Sediment, Shell construction

Abstract

The study of benthic foraminifera in a complex marine system, like the Marmara Sea, is a key for understanding the influence of environmental factors on foraminiferal species, density, assemblage composition, and shell construction. This kind of study is important for further extensive use of foraminifera-based investigation of water mass and sediment exchange between the eastern Mediterranean and Black Sea through the Marmara Sea. Based on proximal-distal transect from the southwest coast of the Erdek Bay to the top of canyon close to the North Anatolian Fault, this study aims at defining the geochemical conditions at the seafloor and identifying the sediment constraints that act upon agglutinated test construction for selected species (Eggerelloides scaber, Textularia agglutinans, Textularia 
sagittula, Textularia truncata and Textularia bocki). Grain size, mineralogical, and chemical analyses of their shells were investigated and confronted with the main geochemical conditions prevailing during deposition and within the sediment. Among grains used to construct the agglutinated foraminiferal tests from available grains, both grain size selection and sorting have been evidenced. This suggests that the mineralogical composition is related to the species and the sample localization within the basin. Our observations further suggest that bottom water conditions of the Marmara Sea do not have a significant influence on agglutinated foraminiferal shell development, which is primarily driven by sediment characteristics. Our results are thus transposable to other environments.

\section{Introduction}

It is well known that the composition, species diversity and spatial distribution of benthic foraminiferal assemblages are strongly controlled by environmental parameters (Murray, 2006). However, there is still much debate as to which environmental factors have the most significant effect on foraminifera in a specific habitat.

Very few papers address the question of sediment control on the agglutinated foraminifera and their shell mineralogy/chemistry. Although the phenomenon of grain selection among agglutinated foraminifera has been known for over a century (Heron-Allen and Earland, 1909; Heron-Allen, 1915), the mechanisms involved are still not well understood. More recently, Allen et al. (1999), Kaminski et al. (2008) or Armynot du Châtelet et al. (2009) focused on the mineral phases used by agglutinated foraminifera. Makled and Langer (2010), Rothe et al. (2011) or Gooday et al. (2011) studied heavy minerals that can be agglutinated and the mechanisms of agglutination. Additional common species need to be studied with emphasis on the potential environment controls on test construction.

The Marmara Sea is a complex marine system, comprising water masses derived from both high salinity Mediterranean waters (salinity 31-38) and brackish waters from the Black Sea (salinity 14-25) (Aksu et al., 2002b; Mudie et al., 2004). Many studies focus on foraminifera as tool for understanding the influence of water mass movement on sediment distribution in that region because of the reconnection of the Marmara Sea to the Mediterranean Sea after the last glacial episode (e.g., Aksu et al., 2002a; Mudie et al., 2002; McHugh et al., 2008) or sediment dynamics in that sensitive region (North Anatolian active fault with a potentially high human impact (Gökasan et al., 2005). A study of benthic agglutinated benthic foraminifera in this marine system is a key for understanding environmental controls on foraminiferal species density, diversity, and shell construction. 
The objective of this study is to expand agglutinated foraminiferal knowledge on ecological and biogeochemical directions in this exceptional environment. The main goals are:

(1) to geochemically characterise the bottom sediment (major elements and redox proxies, organic matter quality) and to assess whether these parameters are limiting factors for foraminifera;

(2) to identify the sedimentary constraints on agglutinated foraminiferal test construction (grain size, and mineralogical nature). In our study we concentrate on the agglutinated foraminifera as their shell microstructure directly depends on the sediment characteristics, and may even influence the latter.

\section{Study area and previous benthic foraminifera investigation}

The Marmara Sea is a small intercontinental basin situated between the world's largest permanently anoxic basin, the Black Sea, and the northeastern extension of the eastern Mediterranean basin, the Aegean Sea (Fig. 1). Two relatively shallow and narrow straits known as the Dardanelles and the Bosphorus, respectively, are the only connections between the Black Sea and Mediterranean Sea (Fig. 1A and B). Several sills with depths of $\sim 60-70 \mathrm{~m}$ prevent the deepwater transfer between the Aegean Sea, Marmara Sea and Black Sea (Gökasan et al., 2005, 2008). At present, brackish surface water from the Black Sea (salinity down to 14) outflows into the Marmara Sea through the Bosphorus Strait, while saline deeper water from the Aegean Sea (salinity up to 38) flows northwards as a countercurrent (Aksu et al., 2002b; Mudie et al., 2004). This two-way flow is repeated in the Dardanelles Strait, creating an overall estuarine circulation within the Marmara Sea. Due to the outflow of brackish Black Sea water, a strong halocline is present throughout the Marmara Sea, generating low-oxygen and stratified conditions below a thin, well-mixed and oxygenated surface layer (Kaminski et al., 2002; Chendeş et al., 2004).

Studies on foraminifera have been carried out in all three basins, the Easter Mediterranean Sea (Parker, 1958; Cimerman and Langer, 1991), the Black Sea (Yanko and Troitskaja, 1987; Yanko, 1990) and the Marmara Sea (Alavi, 1988; Meriç et al., 1995; Kaminski et al., 2002; Avsar et al., 2006;McHugh et al., 2008). The examination of the diversity of this area had been expanded by Sgarrella and Zei (1993) in Italy, by Rasmussen (2005) in Greece and by Basso and Spezzaferri (2000) in Turkey. The lacustrine to marine transition in the Marmara Sea at $\sim 12$ ka BP was specifically investigated by McHugh et al. (2008). 
Several studies (Chendeş et al., 2004; Phipps, 2007; Frontalini et al., 2011) documented the influence of water mass properties on modern benthic foraminiferal assemblages and identified distinct assemblages across a N-S transect on the southern shelf of the SW Marmara Sea. Phipps et al. (2010) studied calcareous foraminifera in relation to water masses properties without considering the in situ physical and chemical conditions of the sediment. The agglutinated foraminifera in the transect were studied by Frontalini et al. (2011) who focused on the extraordinarily diversified fauna but also characterised it with respect to the water mass properties. None of these studies took into account possible sediment control on the agglutinated foraminiferal ecology and more precisely on the potential impact of the sediment texture and nature on test construction. We thus focus our study on this specific and crucial aspect.

\section{Material and methods}

Samples were collected on board the R/V Koca Piri Reis (Institute of Marine Sciences and Technology, Dokuz Eylül University, Izmir, Turkey) during Cruise MAR-02 in 2002, using a Shipeck grab sampling device. Seventeen samples are taken from the original sampling profile studied by Chendeş et al. (2004) and Frontalini et al. (2011) (Fig. 1C). Sediments were separated in two aliquots: the first one for foraminiferal investigation and the second one for environmental characterisation. Organic and inorganic geochemistry were first studied to evaluate the strongest known constraints on foraminifera (i.e., organic matter and oxygen). The sediment was further characterised by with sediment grain size and clay mineralogy. On foraminifera we measured the chemical composition of the test, the mineralogical nature of the agglutinated grains, their size and their distribution. These characteristics were compared with those of the sediment. Further details, including the material and methods used in this study, are summarised in the Supporting Information Materials and Method (Supplementary data S0).

Statistical analyses were carried out using the integrated suite of software $\mathrm{R}$ and the base, stats and moments packages (R-Development-Core-Team, 2004).

\section{Results}

\subsection{Sediment investigations}

\subsubsection{Sediment grain-size characterization}


The sample set was subdivided into three groups according to the size distribution of the grains: group 1 (samples 3, 7, 9, 11, 13, 15, 17, 19, 92, and 96), group 2 (samples 5, 94, 100, 98, 101, and 99), and group 3 (sample 1) (Fig. 2). Group 1 displays a unimodal distribution ( $95 \%$ confidence interval of the mean mode is $6.50-7.03 \mu \mathrm{m}$ ), but the sediment is very poorly to poorly sorted (sorting index varies from 1.28 to 2.79) (Fig. 2 and Supplementary data S4). Group 2 is characterised by the previous sediment grain population, as well as a second mode (95\% confidence interval of the mean mode is $295-382 \mu \mathrm{m})$. Grains belonging to this second mode are mostly quartz accompanied by some foraminifera. Group 3 is also characterised by two modes, one close from the mode of group $2(7.46 \mu \mathrm{m})$ and a dominating one $(58 \mu \mathrm{m})$. The dominant fraction is clearly the fine silt that contributes to more than half the sediment (Fig. 2 and Supplementary data S4). This fraction tends to increase offshore, but the deepest samples close to the submarine canyon system $(94,98,99,100$ and 101) display a clear increase in sand fraction.

\subsubsection{Clay mineralogy}

All samples are made up of four clay mineral species: smectite $(\sim 63 \%)$, illite $(\sim 19 \%)$, kaolinite $(\sim 10 \%)$ and chlorite ( $8 \%$ ) (Table 1). According to the variation in the proportion of different clay minerals, the hierarchical analysis groups the samples into three distinctive clusters (Fig. 3). Cluster A represented by samples 3, 5 and 7 are the richest in smectite (66$69 \%$ ), with close amount of illite (13-15\%) and kaolinite (12-13\%) and low amount of chlorites $(6-7 \%)$. Sample 1 is enclosed in this group but differs by its highest content of kaolinite (17\%) up to $50 \%$ greater than the other samples. Cluster B is composed of samples 9 to 19 and is characterised by variable percentages of smectite. Cluster $\mathrm{C}$ includes samples 92 to 101 that are located close to the canyon and at the deepest location. These samples are less rich in smectite (54-63\%) and richer in illite (21-25\%), while kaolinite and chlorite contents are low $(7-11 \%)$.

\subsubsection{Calcium carbonate content and organic matter (OM) characterization (C, $N, S, C / N)$}

Calcium carbonate contents are generally low with a mean of $10 \pm 3.3 \%$ (Table 2 ). An increase of the $\mathrm{CaCO}_{3}$ content is clearly correlated to increasing water depth $\left(\mathrm{R}^{2}=0.97\right.$, Supplementary data S5). Samples 94, 98 and 99 located in the canyon show greatest variability of $\mathrm{CaCO}_{3}$ contents. Sample 5 from the shallowest part of the Erdek Bay also plots out of this trend. The mean Corg content is $0.92 \pm 0.31 \%$ (Table 2). Two groups, with the only exception of sample 5 having much higher $\mathrm{CaCO}_{3}$ content, may be considered: from samples 
1 to 92 and 96 with values between 1.01 and $1.26 \%$ and a second group with content lower than $1 \%$ (samples $94,100,101,98$, and 99 ). $\mathrm{CaCO}_{3}$ and Corg are significantly linearly correlated $(-0.69$ on the basis of Pearson correlation analysis; $p=0.002$ and residuals are normally distributed since Shapiro-Wilk test yields: $W=0.8952$ with $p=0.0565$ ). Despite this significant correlation only a minor part of the variation is explained (adjusted $\mathrm{R}^{2}=0.4433$ ). Hence $\mathrm{CaCO}_{3}$ and Corg would be partially independent. Values of the Corg/Ntot ratio do not vary significantly: the mean of Corg/Ntot ranges within a 95\% confidence interval of 8.34 to 9.98. Sulphur amounts are low (95\% confidence interval: 0.10 to $0.15 \%)$ and show a maximum in the middle of the transect (samples 11 to 92 and 96). When presented on a $\mathrm{S}$ vs. Corg diagram, samples can be divided into three groups (Fig. 4). The first group comprises samples 94 and 98 to 101 close to the canyon with low S and low Corg, the second group comprises samples 1 to 9 with low S and high Corg and the last group associate samples 11 to 96 with high S and high Corg.

\subsubsection{Inorganic geochemistry}

4.1.4.1. Major elements. The analyses suggest a clastic-dominated composition with $\mathrm{SiO}_{2}$ and $\mathrm{Al}_{2} \mathrm{O}_{3}$ averaging 49.37 wt.\% and 13.97 wt.\%, respectively (Table 3). The elemental ratios $\mathrm{Fe}_{2} \mathrm{O}_{3} / \mathrm{Al}_{2} \mathrm{O}_{3}, \mathrm{~K}_{2} \mathrm{O} / \mathrm{Al}_{2} \mathrm{O}_{3}, \mathrm{TiO} 2 / \mathrm{Al}_{2} \mathrm{O}_{3}$ and $\mathrm{P}_{2} \mathrm{O}_{5} / \mathrm{Al}_{2} \mathrm{O}_{3}$ show almost invariant values (very low standard deviation compared to the mean). Only the canyon samples show faint but progressive increase in the $\mathrm{SiO}_{2} / \mathrm{Al}_{2} \mathrm{O}_{3}$ ratio together with a concomitant decrease of the $\mathrm{TiO} 2 / \mathrm{Al}_{2} \mathrm{O}_{3}$ ratio.

4.1.4.2. Trace elements. The enrichment factors of redox proxies like trace elements and Mn presented in Table 3 are very close to 1 . It means that there is no authigenic enrichment relative to mean Earth crust values. Moreover, $\mathrm{V}$ and $\mathrm{U}$ are very well correlated to $\mathrm{Al}_{2} \mathrm{O}_{3}$, $\left(\mathrm{p}<<0.001\right.$ with adjusted $\mathrm{R}^{2}$ of respectively 0.939 and 0.653 ). For $\mathrm{U}$, samples $19,96,98,17$, and 92 are not well predicted by the regression model. When these samples are ignored, adjusted $\mathrm{R}^{2}$ becomes 0.964 . These values are also aligned with similar regression slope $(0.66$ vs. 0.61 for the former and $\mathrm{R}^{2}=0.726$ with $\mathrm{p}<<0.001$ ). These good correlations indicate that no authigenic enrichment is observed. In addition, Mo concentration is under the detection limit in most samples $(1.6 \mu \mathrm{g} / \mathrm{g})$. Though of poor quality $\left(\mathrm{R}^{2}=0.55\right)$ there is a significant correlation between $\mathrm{Cu}$ and $\mathrm{Al}_{2} \mathrm{O}_{3}$ ( $\left.\mathrm{p}=0.00036\right)$. When ignoring 3 samples (5, 13 and 94), 78\% of the variability is explained $(\mathrm{p}<<0.001)$. It suggests that $\mathrm{Cu}$ is of detrital origin. In addition, $\mathrm{Cu}$ yields enrichment factors of about 2, which means no detectable authigenic enrichment. 
Nickel shows enrichment factors reaching 4, which indicates weak but detectable authigenic enrichment. Since $\mathrm{Ni}$ is not correlated to $\mathrm{Al}_{2} \mathrm{O}_{3} \quad\left(p=0.228\right.$ with $\left.\mathrm{R}^{2}=0.035\right)$, this faint enrichment may be ascribed to the presence of OM.

\subsection{Foraminifera investigations}

\subsubsection{Characterization of the agglutinated minerals}

4.2.1.1. Distribution of grain sizes. The agglutinated grain size distribution of Eggereloides scaber, Textularia bocki and T. agglutinans follow a log-normal distribution (Table 4a). For T. sagittula and Textularia truncata, grain size is never log-normally distributed, mainly due to the asymmetry and a sharp kurtosis of the distribution (Fig. 5B). The distribution of grainsize sorted by sample (all species pooled) follows a log-normal distribution for most of the samples (Table 4b). At $\mathrm{p}>0.05$, log-normality should be rejected for samples 13, 92, 94, 96, 99 and 101, but it becomes acceptable by slightly changing the probability threshold with $\mathrm{p}>0.01$ (Table 4).

4.2.1.2. Agglutinated grain size statistical dependence on species and on samples. The global range of grain size (surface) used by the five analysed foraminiferal species to construct their test is comparable (Fig. 6). Variance of grain size would be considered as equal between the species (Bartlett's test for homogeneity of variance: Bartlett's K-squared is 3.0511 with a p of 0.55). Eggerelloides scaber used a larger range of grain size than other species (0.2 to 1095 $\mu \mathrm{m}^{2}$ ). Textularia sagittula and T. agglutinans use a narrower range of sizes (from 0.8 and 1 to 326 and $727 \mu \mathrm{m}^{2}$, respectively).

Questioning the dependence of grain size upon species, ANOVA analysis yields an F value: 3.8924 and $\operatorname{Pr}(>F)$ : 0.006526. Hence, the size of the grain agglutinated on the shell is a function of the species $(\operatorname{Pr}(>F)$ threshold $=5 \%)$. Nevertheless, grain size difference between species is not clear-cut as shown by Tukey's test (Table 5). Indeed, all pairs of species should be considered with homogenous mean grain size except $T$. sagittula-E. scaber and $T$. truncata-E. scaber. E. scaber should be considered as slightly different because it agglutinates both smaller and bigger grains.

Questioning the dependence of grain size upon sample, ANOVA results give a F value of 0.6801 and $\operatorname{Pr}(>F)$ of 0.8013 . Hence, the mean size of grains agglutinated on the specimens 
is not dependent on the sample $(\operatorname{Pr}(>\mathrm{F})$ threshold $=5 \%)$. Therefore, distribution of agglutinated grains along the transect should be considered as homogenous.

4.2.1.3. Grain circularity and roundness investigation. A wide range of circularity is observed but the core of the sample set is mainly measured between $\sim 0.60$ and 0.90 (Supplementary data S6a and $b$ ). This means that the shapes of the agglutinated grains are closer to circles than to spines. The roundness ranges, on average, from $\sim 0.55$ to 0.80 (Supplementary data S6c and d). This means that a majority of convex grains are used for shell construction. From visual inspection circularity and roundness of agglutinated grains should be considered as similar between species and between samples.

4.2.1.4. Orientation of grains. All grains are randomly oriented in the shells (Supplementary data S7). The distribution of the orientation of the grains are assimilated to a standard uniform distribution according to a probability $>5 \%$ obtained for all the grains grouped by species and by sample with a Kolmogorov-Smirnov test comparing the distribution of the orientation of the grains with a randomly generated theoretical uniform distribution. Moreover, these grain orientations are neither dependent on the species (ANOVA results: $F$ value $=0.253$ and $\operatorname{Pr}(>F$ ) of 0.907 ) nor on the samples (ANOVA results: $F$ value $=0.648$ and $\operatorname{Pr}(>F)$ of 0.8307 ).

\subsubsection{Geochemistry of agglutinated shells}

4.2.2.1. Mineral diversity. For minerals determined by Raman spectrometry amongst 133 analysed grains, 107 were identified (Supplementary data S8). For the 27 remaining grains, spectra were not clear enough for accurate determination. A total of 21 different mineral species were recognised. According to such a large panel of mineral species and to the low number of analyses, it is not possible to define any mineral character for each foraminiferal species.

For the 55 grains analysed by SEM-EDS, feldspar (60\% of analysed grains) are dominated by $\sim 70 \%$ plagioclase (with three subgroups: Anorthite ${ }_{0-10}$, Anorthite An-50, $_{3}$, Anothite $_{65-70}$ ) and about $30 \%$ of near- Orthoclase 100 alkali feldspar. Other grains comprise $\sim 10 \%$ of pure silica and $\sim 10 \%$ of $(\mathrm{Ca}, \mathrm{Fe}, \mathrm{Mg}$ )-silicates (such as pyroxene, amphibole or chlorite). Only one grain of calcite, sphene, Fe-Ti oxide and zircon was found. Neither muscovite nor biotite has been detected. 
4.2.2.2. Foraminiferal surface chemistry. Semiquantitative measurements of the whole shell surface suggest that oxide compositions differ between species (Fig. 7). The oxide proportion of E. scaber is the most different relative to the other species (Fig. 7).

4.2.2.3. Quartz proportion and distribution. After SEM-EDX surface analysis, and point analyses, quartz appears to be the dominant mineral and could be precisely quantified. Quartz proportions are significantly different between the five tested species and between the samples (Table 6a). The proportion of quartz grains in Eggereloides scaber differs clearly from the other species (Table 6b) and is on average, the highest (Fig. 8). The proportion of quartz in Textularia bocki is the lowest of the studied species. The quartz proportion of specimens from samples 1 and 3 is globally much higher than for the others, where quartz proportion is similar (Table $6 \mathrm{c}$ ).

4.3. Comparison between physical and chemical structure of shells and sediment characteristics

\subsubsection{Grain size differences between foraminiferal shell and sediment}

Sediment grain sizes are compared with size of the grains used by the agglutinated by foraminifera (Fig. 9). For all the five tested species, agglutinated grains in the shell generally correspond to the finest available grains with a mean surface of $6.5 \mu \mathrm{m} 2$. Eggerelloides scaber displays the poorest fit to sediment grain size, with an overrepresentation of the finest grains. The grains used by Textularia sagittula, T. truncata and T. bocki are in the same proportion as the smallest grains of the sediment. Textularia agglutinans agglutinates grains that dominate the sediment (Fig. 9).

\subsubsection{Chemical fractionation between foraminiferal shell and sediment}

The chemical compositions of the foraminiferal shells and the sediment are always different. ANOVA indicates that none of the chemical compositions (sediment, foraminifera grains grouped by species or grouped by sample) are comparable (Supplementary data S9).

\section{Discussion}

\subsection{Marmara Sea bottom sediment conditions}




\subsubsection{Inorganic geochemistry}

Major element distribution suggests that the canyon sediments could be slightly enriched in quartz particles (sand and silt size) as echoed by the slight increase of the $\mathrm{SiO}_{2} / \mathrm{Al}_{2} \mathrm{O}_{3}$ ratio. The remaining samples show very low variation in the element distribution.

Trace metal distribution suggests that particle accumulation on the foraminiferal shell took place under normal marine conditions, characterised by normal productivity in surface water and oxygenated bottom water. Moreover, the sediment did not record any authigenic enrichment of redox markers. Hence, sediment accumulation must have occurred in a normally-oxygenated marine water-mass with no reducing conditions recorded at the watersediment interface. Nevertheless, the benthic oxygen level must be low in the deepest parts of the transect as indicated by the presence of a fauna rich in Brizalina, a genus that is tolerant to low oxygen level (Chendeş et al., 2004; Phipps et al., 2010). Consequently, benthic foraminifera develop in this part of the Marmara Sea under bottom-water oxygen conditions that must be close to the lower boundary of normal-marine conditions.

\subsubsection{Organic geochemistry and sediment characteristics}

The OM quantity and quality are among the most widely analysed parameters in relation to the foraminiferal ecosystem (Hayward et al., 1996; Buosi et al., 2012). OM could influence the diversity and density of the foraminiferal assemblages. It is also known that some species reproduce and develop under definite OM conditions (Alve, 1994, 1999), which may become a limiting factor depending on threshold values (Murray, 2001). Here no influence of $\mathrm{OM}$ on the foraminiferal distribution was documented.

The $\mathrm{C} / \mathrm{N}$ values indicate that the $\mathrm{OM}$ is principally of phytoplankton origin with a probable small terrestrial contribution (Berner and Raiswell, 1984) slightly increasing landward on the southern area. When presented on a S vs. Corg diagram, samples plot below the "normal marine" line that corresponds to fine-grained, siliciclastic sediments undergoing slightly reducing conditions after deposition (Berner, 1982; Berner and Raiswell, 1984). Such a behaviour can result from a normal oxygenation of bottom waters and/or from the presence of freshwater inputs that limit bacterial sulphate reduction (Berner, 1982; Berner and Raiswell, 1984). Apart from surface water with low salinity (16-20\%), the salinity in the Marmara Sea is close to that of normal sea water (salinity range 31 to 38) (Chendeș et al., 2004), so that only shallow sediments bathed by surface water should be sulphate-limited. The low S/Corg values of the sediment could also result from the occurrence of a certain proportion of terrestrial OM that is less readily degradable than marine OM (e.g. Hedges et 
al., 1988). However, a high contribution of terrestrial OM to the sediment is not confirmed by the low Corg/Ntot values. Therefore, the generally low S/Corg values probably reflect sufficient oxygenation of the sediment.

When examined in greater detail, the samples can be divided into three groups.

(1) The first group comprises samples 94 and 98 to 101, which were also grouped according to sediment grain size characteristics. These samples are poor both in S and Corg. These very low values are consistent with a well oxygenated sediment where OM is strongly degraded and very low amounts of reduced sulphur are formed. This good oxygenation is also consistent with the highest proportion of coarse grains that indicates a relatively high-energy environment. In a normal marine profile we would expect to find a decrease in grain size towards the deepest part of the transect and low oxygen conditions within a low energy environment. Contrary to expectations, the conditions observed for this group of samples are probably influenced by the submarine canyon, which represents a highenergy environment with multiple deep-water sources, coarser grains, and good oxygenation.

(2) The second group, situated in the middle of the transect, corresponds to samples 11 to 92 and 96. These sediments are more enriched both in Corg and S. Slightly more reducing (dysoxic) conditions could develop in the sediment in relation to the higher organic content, however, as indicated by the absence of authigenic $\mathrm{U}$ and $\mathrm{V}$ enrichments, the sediment generally remains well oxygenated, so that anoxia, if present, probably only developed in micro-environment. It is also consistent with sediment grain size that indicates a quieter environment than that documented in the deepest sites.

(3) The third group comprises samples 1 to 9 (except for sample 5), where the sediment is rich in $\mathrm{OM}$ and poor in $\mathrm{S}$. These low values are consistent with well oxygenated conditions in the sediment, however, the marked depletion in S compared to the second group points to limitations for bacterial sulphate reduction. This group corresponds to the shallowest stations, which are more or less bathed by the low salinity surface water of the Marmara Sea. The salinity of these surface waters is close to the $18 \%$ o threshold under which sulphate becomes limiting (Berner and Raiswell, 1984). A further decrease in salinity could, however, result from freshwater influx from local rivers. In addition, a slight increase in the proportion of terrestrial $\mathrm{OM}$ is indicated by the slightly higher values of the Corg/Ntot ratio. Such an increase would also limit sulphate reduction in these sediments. 
As a conclusion, the organic and inorganic geochemistry demonstrated that there are no apparent limiting factors at the Marmara sea floor. It should be stressed that the samples close to the canyon undergo more dynamic sedimentary conditions.

\subsection{Impact of environmental conditions on foraminifera}

The development, settlement, reproduction and growth of benthic agglutinated foraminifera should hence depend primarily on sediment grain size and mineralogical composition.

\subsubsection{Sediment grain size}

There is a close relationship between sediment type, mode of life and test morphology (Corliss, 1991; Armynot du Châtelet et al., 2009). Foraminifera usually prefer clayey and silty habitats where larger density and diversity are observed (Szarek et al., 2006). For agglutinated species the mechanisms are amplified because sediment is not only a habitat but also a source of material for test building.

However, at the species taxonomic level, some species prefer clayey, others prefer silty, and others prefer coarse sediments (Szarek et al., 2006). Foraminiferal shells should be intimately correlated to sedimentary substrate because of at least one of these two reasons.

The clay fraction permits the precise identification of local sources of provenance and surrounding fluvial drainage basins together with dilution and distribution effects by current transport processes. Illite is characteristic of the northwest land masses bordering the Marmara Sea, where it mainly derives from sedimentary and metamorphic formations outcropping in the hinterland (e.g., Pehlivanoglou et al., 2000; Poulos et al., 2000). Previous studies revealed that smectite has a rather homogenous distribution in the Marmara Sea and it may be supplied in the south-western part of the Marmara Sea, where it derives from the weathering of volcanic rocks (Bayhan et al., 2001; Kazanci et al., 2004). Smectite may also be supplied in the northern part of the Marmara Sea via the Black Sea outflow water (Müller and Stoffers, 1974; Erhmann et al., 2007).

Kaolinite-rich Tertiary formations bounding the south-western part of the Marmara (Lake Manyas) and the Dardanelles Strait (Bayhan et al., 2001; Kazanci et al., 2004) are the main sources of kaolinite. The increased contribution in kaolinite at the southern sites reflects 
the primary composition of the adjacent land, while illite is more abundant in the northern sites (potential sources are described in Pehlivanoglou et al., 2000; Poulos et al., 2000). The abundance of smectite associated with a smectite/kaolinite ratio showing a maximum in the mid-part of the transect suggests that smectite is transported as suspended material together with the Black Sea outflow water, as described by Müller and Stoffers (1974), Erhmann et al. (2007). The clay mineralogy of surface sediments from the Marmara Sea transect is first controlled by a basin-wide distribution of smectite, associated with local supplies within the basin as revealed by the southward decrease of the illite/kaolinite ratio. The observations of various terrigenous suppliers toward the basin are in accordance with results of Ergin et al. (2012) in the Gulf of Izmit, in the northern part of the Marmara Sea. Finally, the overrepresentation of smectite compared with the other clay particles suggests that clay mineralogy could not be considered as either a limiting or favouring factor for foraminiferal development.

The Marmara Sea sediments are predominantly composed of sand in the northern and deepest part of the transect, which likely reflects on the one hand winnowing caused by the denser winter inflow of Mediterranean water (Phipps et al., 2010) and on the other hand sediment contribution from the canyon environment (McHugh et al., 2006). Larger particles characterising shelly sands apparently provide both shelter and attachment surfaces, and constitute a stable substrate for epifaunal feeding (Murray, 1986; Schönfeld, 2002). Moreover, Buosi et al. (2012) observed an increase of the proportion of agglutinated foraminifera in sandy sediment. Especially, the thick test of infaunal species (like the genus Textularia) enables them to live in coarser surface sediment.

In the Marmara Sea, the shell grain-size distributions are generally biased towards the smaller sediment grain-size (fine and sortable silt) that is used dominantly, excluding the coarser grains. Many species of agglutinated foraminifera do not select or only weakly select the grains into their test (Thomsen and Rasmusen, 2008). Other species may be strongly selective (e.g., Allen et al., 1998) choosing grains of specific shape and size. In the Marmara Sea, the grain size distribution of the shell often evidences a grain selection process relative to the available sediment grains (e.g. Fig. 9, Textularia sagittula, sample 7) and in general tend to select the lower half of the lower mode (e.g., Fig. 9. T. truncata, sample 99). Some offsets are, nevertheless, observed with some species probably depending on specific construction pattern. This kind of grain size fractionation between the foraminifera and the sediment is known, and has already been described for example for Astrammina rara (Bowser and 
Bernhard, 1993). As a conclusion, we infer that in the present-day sediments of the Marmara Sea, small grains (silt) are important for shell development and coarse grains (sand), favour the settlement of agglutinated species.

Log-normal grain distributions suggest that Textularia bocki, Eggereloides scaber and T. agglutinans produce precisely constructed tests. Referring to Fig. 2 of Tuckwell et al. (1999), this log-normal, or nearly log-normal distribution implies that larger spaces in the wall between grains should be filled by a larger volume of organic cement, compared with fractal size distribution. It is most probable that log-normal grain distribution is the result of a strict exclusion of small grains indicated by the under-representation of grains smaller than $0.5 \mu \mathrm{m}$. As the mode of grain size distribution is of a magnitude greater than the lowest measurable size, log normal distribution should reflect the observable grain size range. On the other hand, Tuckwell et al. (1999) observed that smaller grains are "not present" and the larger grains have been positioned to fit closely together. In our study, we observed 76 specimens in which we demonstrate that the small available grains are also used even in lognormal distribution.

Preferential spatial orientation of grains that would suggest an optimisation of available space in shells has not been observed. This explains why the volume of organic cement is not high compared with the grain surface. It corroborates the formerly developed idea of infilling of larger gaps with grains irrespective of their position and orientation. A 3dimensional study at one order of magnitude greater resolution (X-ray micro-tomography, work in progress) might yield a better grain size characterization.

\subsubsection{Sediment chemistry}

Foraminifera with calcite shells precipitate them in equilibrium with sea water. Some species with agglutinated shells are more complex, being able to select grains with peculiar geochemistry (Heron-Allen and Earland, 1909; Heron-Allen, 1915; Allen et al., 1999). Moreover, as already seen in a similar study in a coastal area, the composition of the sediment is not a limiting factor for the settling and development of the agglutinated foraminifera (Armynot du Châtelet et al., 2009). Whatever the process in the Marmara Sea the foraminifera are able to generate a chemical fractionation between their own shell and the sediment in which they live. To account for this fractionation, we can stress that mica (biotite and muscovite) is absent and that predominant mineral species form stubby grains and/or have a 
high density. Shell surface bulk geochemistry is also very variable depending on the species. Each species agglutinates its own proportion of the dominant mineral, quartz. These proportions are also a function of the sample location.

\subsubsection{E. scaber peculiarities}

E. scaber is different from other species and is demonstrated to be more selective. This species agglutinates more quartz than others. Correspondingly, the bulk shell chemical composition is richer in $\mathrm{SiO}_{2}$. The shell grain size range is the largest with the highest proportion of smallest grains.

\section{Conclusions}

The surficial sediment in the western Marmara Sea can be subdivided into two groups with respect to observed geochemistry, redox conditions, and organic chemistry: shelf sediments deposited under normal marine conditions, and slope sediments with coarser grain size, bimodal grain size populations, larger $\mathrm{CaCO}_{3}$ content range, and more oxygenated conditions. The latter probably reflect high-energy environment in deeper water under the influence of Mediterranean inflow water, and/or of earthquake-induced reworking along the North Anatolian fault zone.

In such persistently well-oxygenated conditions, we observe the following agglutination pattern among the agglutinated foraminifera:

- $\quad$ The size of the grains observed on shells frequently belongs to the lower half of the available size range. A grain size weak fractionation is observed for $T$. bocki, E. scaber and T. agglutinans. No preferential orientation of grains could be detected by 2-dimensional SEM observations combined with image analysis.

- $\quad$ The chemical composition of the shells shows fractionation relative to the sediment chemistry. This fractionation itself appears to be controlled by the species and by the sample location. In particular, the proportion of quartz used by the foraminifer is species-dependent.

- $\quad$ The gradients in the Marmara Sea are unexpected as coarser and oxygenated in the deepest part. In those exceptional conditions, the different sediment 
dynamics on the floor of the Marmara Sea do not have any influence on the agglutinated benthic foraminiferal shell development that could trigger foraminiferal assemblages. The $\mathrm{Om}$ and oxygenation conditions that are present in the Marmara Sea remain the dominant factor. As a consequence, foraminiferal assemblages could be used for past reconstruction without checking the chemical and physical environmental conditions of the surroundings sediments. Moreover, our results can be transposed to other marine environments.

Supplementary data to this article can be found online at http:// dx.doi.org/10.1016/j.margeo.2012.10.013.

\section{Acknowledgements}

The authors thank Laurent Alleman from Ecole des Mines de Douai for analysing trace elements. MAK thanks Ali Aksu (Memorial University of Newfoundland) for the opportunity to participate in the MAR02 cruise. The authors are grateful to the two anonymous reviewers as well as the co-editor in chief David J.W. Piper for the thorough suggestions and revisions.

\section{References}

Aksu, A.E., Hiscott, R.N., Kaminski, M.A., Mudie, P.J., Gillespie, H., Abrajano, T., Yasar, D., 2002a. Last Glacial-Holocene paleoceanography of the Black Sea and Marmara Sea: stable isotopic, foraminiferal and coccolith evidence. Marine Geology 3160, 1-31.

Aksu, A.E., Hiscott, R.N., Mudie, P.J., Rochon, A., Kaminski, M.A., Abrajano, T., Yasar, D., 2002b. Persistent Holocene outfow from the Black Sea to the Eastern Mediterranean contradicts Noah's Flood hypothesis. GSA Today 12, 4-9.

Alavi, S.N., 1988. Late Holocene deep-sea benthic foraminifera from the Sea of Marmara. Marine Micropaleontology 13, 213-237.

Allen, J.R.L., Robert, S., Murray, J.W., 1998. Fractal grain distribution in agglutinated foraminifera. Paleobiology 24, 349-358. 
Allen, K., Robert, S.,Murray, J.W., 1999. Marginal marine agglutinated foraminifera: affinities for mineral phases. Journal of Micropalaeontology 18, 183-191.

Alve, E., 1994. Opportunistic features of the foraminifer Stainforthia fusiformis (Williamson): evidence from Frierfjord, Norway. Journal of Micropalaeontology 13, 24.

Alve, E., 1999. Colonization of new habitats by benthic foraminifera: a review. EarthScience Reviews 46, 167-185.

Armynot du Châtelet, E., Bout-Roumazeilles, V., Riboulleau, A., Trentesaux, A., 2009. Sediment (grain size and clay mineralogy) and organic matter quality control on living benthic foraminifera. Revue de Micropaleontologie 52, 75-84.

Avsar, N., Aksu, A., Dincer, F., 2006. Benthic foraminiferal assemblages of the Erdek Bay (SW Marmara Sea). [in Turkish] Yerbilimleri [Journal of the Earth Sciences Application and Research Center of Hacettepe University] 27, 125-141.

Basso, D., Spezzaferri, S., 2000. The distribution of living (stained) benthic foraminifera in Iskenderun Bay (Eastern Turkey): a statistical approach. Bollettino della Società Paleontologica Italiana 39, 359-379.

Bayhan, E., Ergin, M., Temel, A., Keskin, S., 2001. Sedimentology and mineralogy of surficial bottom deposits from the Aegean-Canakkale-Marmara transition (Eastern Mediterranean): effects of marine and terrestrial factors. Marine Geology 175, 297-315.

Berner, R.A., 1982. Burial of organic carbon and pyrite sulfur in the modern ocean: its geochemical and environmental significance. American Journal of Science 282, 451-473.

Berner, R.A., Raiswell, R., 1984. C/S methods for distinguishing freshwater from marine sedimentary rocks. Geology 12, 365-368.

Bowser, S.S., Bernhard, J.M., 1993. Structure, bioadhesive, and elastic properties of the agglutinated test of Astrammina rara. The Journal of Eukaryotic Microbiology 40, 121-131.

Buosi, C., Armynot du Châtelet, E., Cerchi, A., 2012. Environmental parameter constraints for benthic foraminifera in the strait of Bonifacio (Mediterranean Sea). Journal of Foraminiferal Research 42, 39-55.

Chendeş, C., Kaminski, M.A., Filipescu, S., Aksu, A., Yasar, D., 2004. The response of modern foraminiferal assemblages to water-mass properties along the southern shelf of the Marmara Sea. Acta Palaeontologica Romaniae 4, 69-80. 
Cimerman, F., Langer, M.R., 1991. Mediterranean foraminifera, Ljubljana. 118 pp.

Corliss, B.H., 1991. Morphology and microhabitat preferences of benthic foraminifera from the northwest Atlantic Ocean. Marine Micropaleontology 17, 195-236.

Ergin, M., Bayhan, E., Temel, A., 2012. Clay mineral distribution in last Glacial-Holocene sediment cores from the eastern Marmara Sea (Çınarcık Basine_Izmit Gulf Transition), NWTurkey: multisources and transport paths in a two-way flow system. Quaternary International $261,53-74$.

Erhmann, W., Schmiedl, G., Hamann, Y., Kuhnt, T., 2007. Distribution of clay minerals in surface sediments of the Aegean Sea: a compilation. International Journal of Earth Sciences 96, 769-780.

Frontalini, F., Kaminski, M.A., Coccioni, R., Bucci, C., Aksu, A., 2011. Bathymetric distribution and ecological characterization of agglutinated foraminifera along an inner neritic to upper bathyal transect in the Marmara Sea. In: M.A.F., Kaminski, S. (Eds.), Proceedings of the Eighth International Workshop on Agglutinated Foraminifera, pp. 37-52.

Gökasan, E., Algan, O., Tur, H., Meriç, E., Türker, A., Simsek, M., 2005. Delta formation at the southern entrance of Istanbul Strait (Marmara Sea, Turkey): a new interpretation based on high-resolution seismic stratigraphy. Geo-Marine Letters 25, 370-377.

Gökasan, E., Ergin, M., Ozyalvac, M., Ibrahim Sur, H., Tur, H., Görum, T., Ustaömer, T., Gul Batuk, F., Alp, H., Birkan, H., Turker, A., Gezgin, E., Ozturan, M., 2008. Factors controlling the morphological evolution of the Canakkale Strait (Dardanelles, Turkey). Geo-Marine Letters 28, 107-129.

Gooday, A.J., Aranda da Silva, A., Pawlowski, J., 2011. Xenophyophores (Rhizaria, Foraminifera) from the Nazaré Canyon (Portuguese margin, NE Atlantic). Deep Sea Research Part II: Topical Studies in Oceanography 58, 2401-2419.

Hayward, B.W., Grenfell, H., Cairns, G., Smith, A., 1996. Environmental controls on benthic foraminiferal and thecamoebian associations in a New Zealand tidal inlet. Journal of Foraminiferal Research 26, 150-171.

Hedges, J.I., Clark, W.A., Cowie, G.L., 1988. Fluxes and reactivities of organic matter in a coastal marine bay. Limnology and Oceanography 33, 1137-1152. 
Heron-Allen, E., 1915. A short statement upon the theory, and the phenomena of purpose and intelligence exhibited by the Protozoa, as illustrated by selection and behaviour in the Foraminifera. Journal of the Royal Microscopical Society 1915, 547-557.

Heron-Allen, E., Earland, A., 1909. On a new species of Technitella from the North Sea, with some observations upon selective power as exercised by certain species of Arenaceous Foraminifera. Journal of the Quekett Microscopical Club 10, 403-412.

Kaminski, M.A., Aksu, A., Box, M., Hiscott, R.N., Filipescu, S., Al-Salameen, M., 2002. Late Glacial to Holocene benthic foraminifera in the Marmara Sea: implications for Black Sea-Mediterranean Sea connections following the last deglaciation. Marine Geology 190, $165-202$.

Kaminski, M.A., Armitage, D.A., Jones, A.P., Coccioni, R., 2008. Shocked diamonds in agglutinated foraminifera from the Cretaceous/Paleogene boundary, Italy - a preliminary report. In: Kaminski, M.A., Coccioni, R. (Eds.), Proceedings of the Seventh International Workshop on Agglutinated Foraminifera. Grzybowski Foundation Special Publication, Urbino, Italy, pp. 57-61.

Kazanci, N., Leroy, S., Ileri, O., Emre, O., Kibar, M., Oncel, S., 2004. Late Holocene erosion in NW Anatolia from sediments of Lake Manyas, Lake Ulubat and the southern shelf of the Marmara Sea, Turkey. Catena 57, 277-308.

Makled, W.A., Langer, M.R., 2010. Preferential selection of titanium-bearing minerals in agglutinated Foraminifera: ilmenite (FeTiO3) in Textularia hauerii d'Orbigny from the Bazaruto Archipelago, Mozambique. Revue de Micropaleontologie 53, 163-173.

McHugh, C.M.G., Seeber, L., Cormier, M.-H., Dutton, J., Cagatay, N., Polonia, A., Ryan, W.B.F., Gorur, N., 2006. Submarine earthquake geology along the North Anatolia Fault in the Marmara Sea, Turkey: a model for transform basin sedimentation. Earth and Planetary Science Letters 248, 661-684.

McHugh, C.M.G., Gurung, D., Giosan, L., Ryan, W.B.F., Mart, Y., Sancar, U., Burckle, L., Çagatay, M.N., 2008. The last reconnection of the Marmara Sea (Turkey) to the World Ocean: a paleoceanographic and paleoclimatic perspective. Marine Geology 255, 64-82.

Meriç, E., Yanko, V., Avsar, N., 1995. Foraminiferal fauna of the Quaternary sequence in the Gulf of Izmit (Hersek Burnu-Kaba Burun). (in Turkish) In: Meriç, E. (Ed.), Izmit Körfezi 
Kuvaterner Istifi. (The Quaternary Succession in Izmit Bay). Deniz Harp Okulu Komutanlisi Basimevi (Maritime Military School Printing Office), Izmit, p. 354.

Mudie, P.J., Rochon, A., Aksu, A.E., Gillespie, H., 2002. Dinoflagellate cysts, freshwater algae and fungal spores as salinity indicators in Late Quaternary cores from Marmara and Black seas. Marine Geology 190, 203-231.

Mudie, P.J., Rochon, A., Aksu, A.E., Gillespie, H., 2004. Late glacial, Holocene and modern dinoflagellate cyst assemblages in the Aegean-Marmara-Black Sea corridor: statistical analysis and re-interpretation of the early Holocene Noah's Flood hypothesis. Review of Palaeobotany and Palynology 128, 143-167.

Müller, G., Stoffers, P., 1974. Mineralogy and petrology of Black Sea basin sediments. In: Degens, E.T., Ross, D.A. (Eds.), The Black Sea - Geology, Chemistry and Biology: AAPG Mem. , pp. 200-248.

Murray, J.W., 1986. Living and dead Holocene foraminifera of Lyme Bay, Southern England. Journal of Foraminiferal Research 16, 347-352.

Murray, J.W., 2001. The niche of benthic foraminifera, critical thresholds and proxies. Marine Micropaleontology 41, 1-7.

Murray, J.W., 2006. Ecology and Applications of Benthic Foraminifera. Cambridge University Press, Cambridge . (426 pp.).

Parker, F.L., 1958. Eastern Mediterranean foraminifera. Sediment cores from the Mediterranean and Red Sea. Report of the Swedish Deep Sea Expedition, p. 8.

Pehlivanoglou, K., Tsirambides, A., Trontsios, G., 2000. Origin and distribution of clay minerals in the Alexandroupolis Gulf, Aegean Sea, Greece. Estuarine, Coastal and Shelf Science 51, 61-73.

Phipps, M., 2007. Calcareous Benthic Foraminiferal Morphogroups from the Sea of Marmara (Turkey): A test of the Kaiho Benthic Foraminiferal Oxygen Index in the Eastern Mediterranean. University College of London, London. 71 pp.

Phipps, M.D., Kaminski, M.A., Aksu, A.E., 2010. Calcareous benthic foraminiferal biofacies along a depth transect on the southwestern Marmara shelf (Turkey). Micropaleontology 56, $377-392$. 
Poulos, S.E., Chronis, G.T., Collins, M.B., Lykousis, V., 2000. Thermaikos Gulf coastal system, NW Aegean Sea: an overview of water/sediment fluxes in relation to air- land-ocean interactions and human activities. Journal of Marine Systems 25, 47-76.

Rasmussen, T.L., 2005. Systematic paleontology and ecology of benthic foraminifera from the Plio-Pleistocene Kallithea Bay section, Rhodes, Greece. Cushman Foundation Special Publication 39, 53-157.

R-Development-Core-Team, 2004. R: A Language and Environment for Statistical Computing, Vienna, Austria.

Rothe, N., Gooday, A.J., Pearce, R.B., 2011. Intracellular mineral grains in the xenophyophore Nazareammina tenera (Rhizaria, Foraminifera) from the Nazare Canyon (Portuguese margin, NE Atlantic). Deep Sea Research Part I: Oceanographic Research Papers $58,1189-1195$.

Ryan, W.B.F., Carbotte, S.M., Coplan, J.O., O'Hara, S., Melkonian, A., Arko, R., Weissel, R.A., Ferrini, V., Goodwillie, A., Nitsche, F., Bonczkowski, J., Zemsky, R., 2009. Global multi-resolution topography synthesis. Geochemistry, Geophysics, Geosystems 10, Q03014.

Schönfeld, J., 2002. A new benthic foraminiferal proxy for near-bottom current velocities in the Gulf of Cadiz, northeastern Atlantic Ocean. Deep Sea Research Part I: Oceanographic Research Papers 49, 1853-1875.

Sgarrella, F., Moncharmont Zei, M., 1993. Benthic foraminifera of the Gulf of Naples (Italy): systematics and autoecology. Bollettino della Società Paleontologica Italiana 32, 145-264.

Szarek, R., Kuhnt, W., Kawamura, H., Kitazato, H., 2006. Distribution of recent benthic foraminifera on the Sunda Shelf (South China Sea). Marine Micropaleontology 61, 171-195.

Thomsen, E., Rasmusen, T.L., 2008. Coccolith-agglutinated foraminifera from the early Cretaceous and how they constructed their tests. Journal of Foraminiferal Research 38, 193214.

Tuckwell, G.W., Allen, K., Roberts, S., Murray, J.W., 1999. Simple models of agglutinated foraminifera test construction. The Journal of Eukaryotic Microbiology 46, 248-253.

Yanko, V.V., 1990. Stratigraphy and paleogeography of the marine Pleistocene and Holocene deposits of the southern seas of the USSR. Memorie della Società Geologica Italiana 44, 167187. 
Yanko, V.V., Troitskaja, T.S., 1987. Late Quaternary foraminifera of the Black Sea (in Russian). Trudy Instituta Geologii I Geofisiki, Akademiya Nauk SSSR, Novosibirsk 694. 


\section{Figure captions}

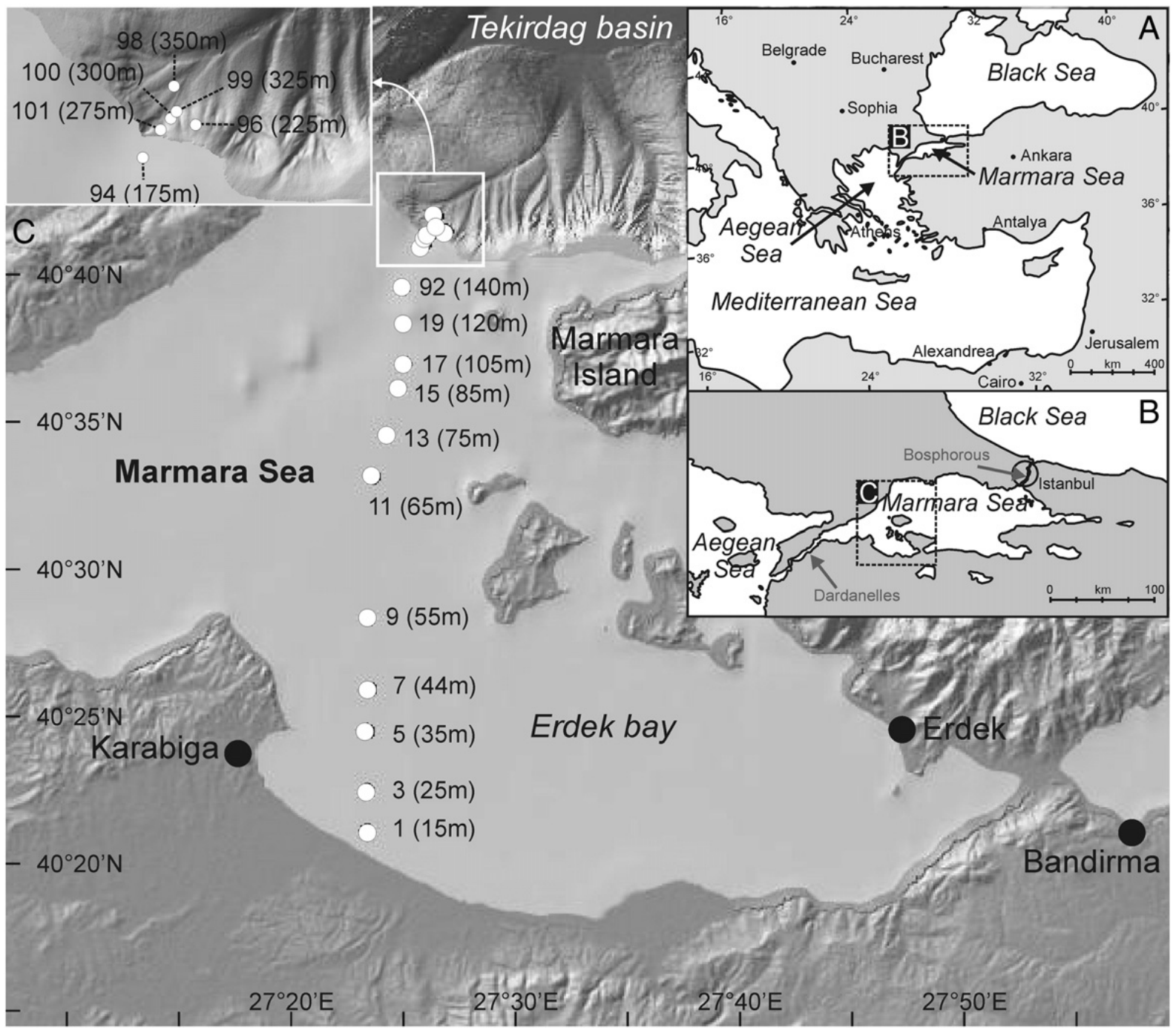

Fig. 1. Study area. (A) Localisation of the Marmara Sea between the Black Sea and the Mediterranean Sea. Base map is extracted from GeoMapApp database http://www. geomapapp.org (Ryan et al., 2009). (B) Details of the Marmara Sea. (C) Sampling area and location of the sample along the profile. The sampling depth is indicated in brackets. 


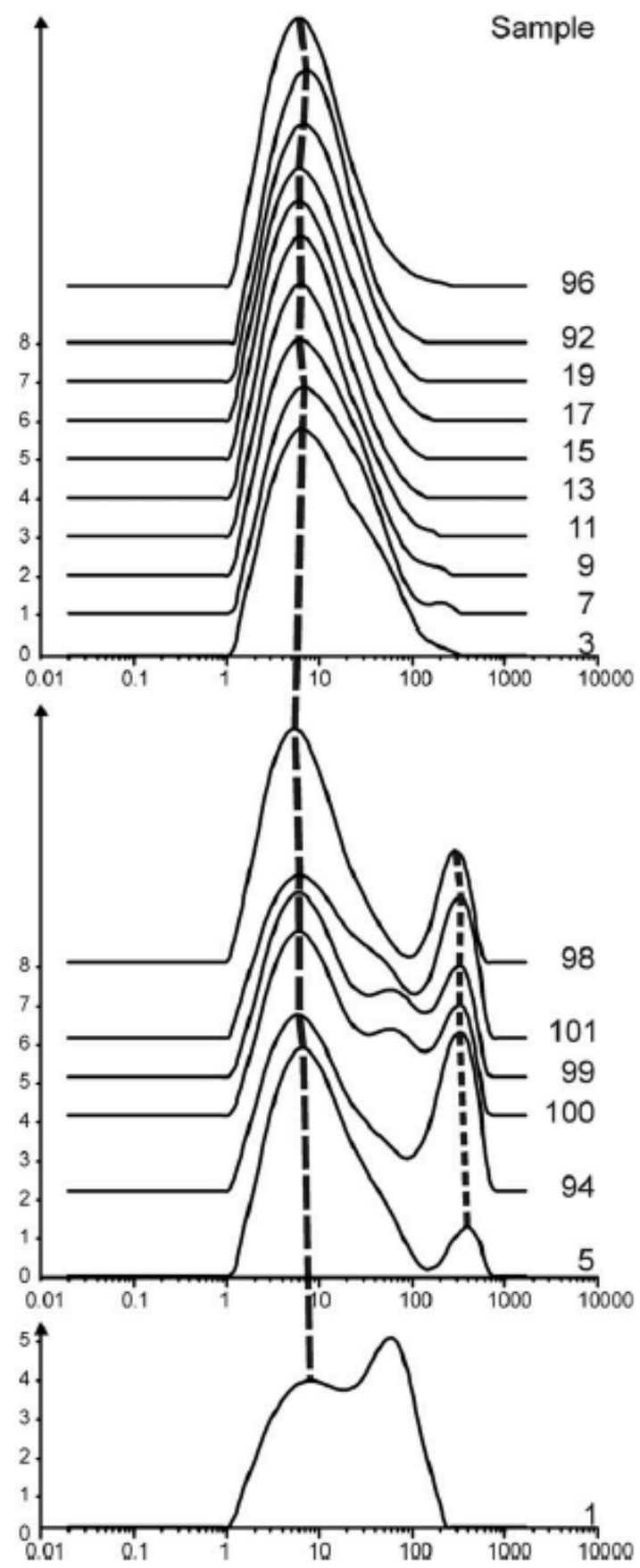

Fig. 2. Sediment grain-size distribution. Three populations are defined. Common modes are marked by thick broken lines. 


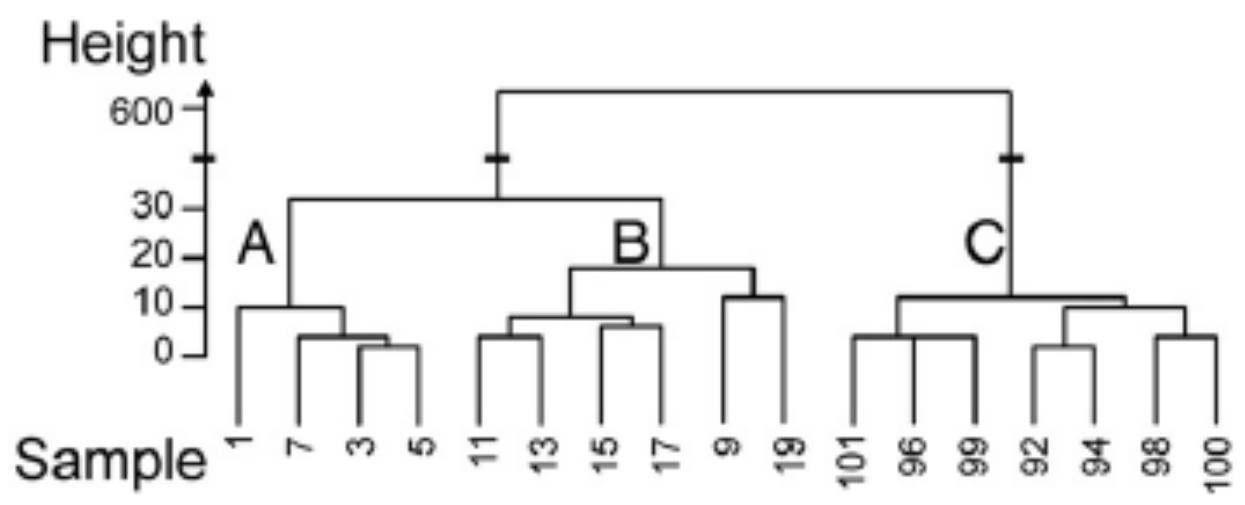

Fig. 3. Cluster analysis carried out on clay mineralogy proportions of four mineral species (smectite, illite, chlorite and kaolinite). Similarity tree is produced using Euclidean distance. Ward's minimum variance method is used as clustering method. 


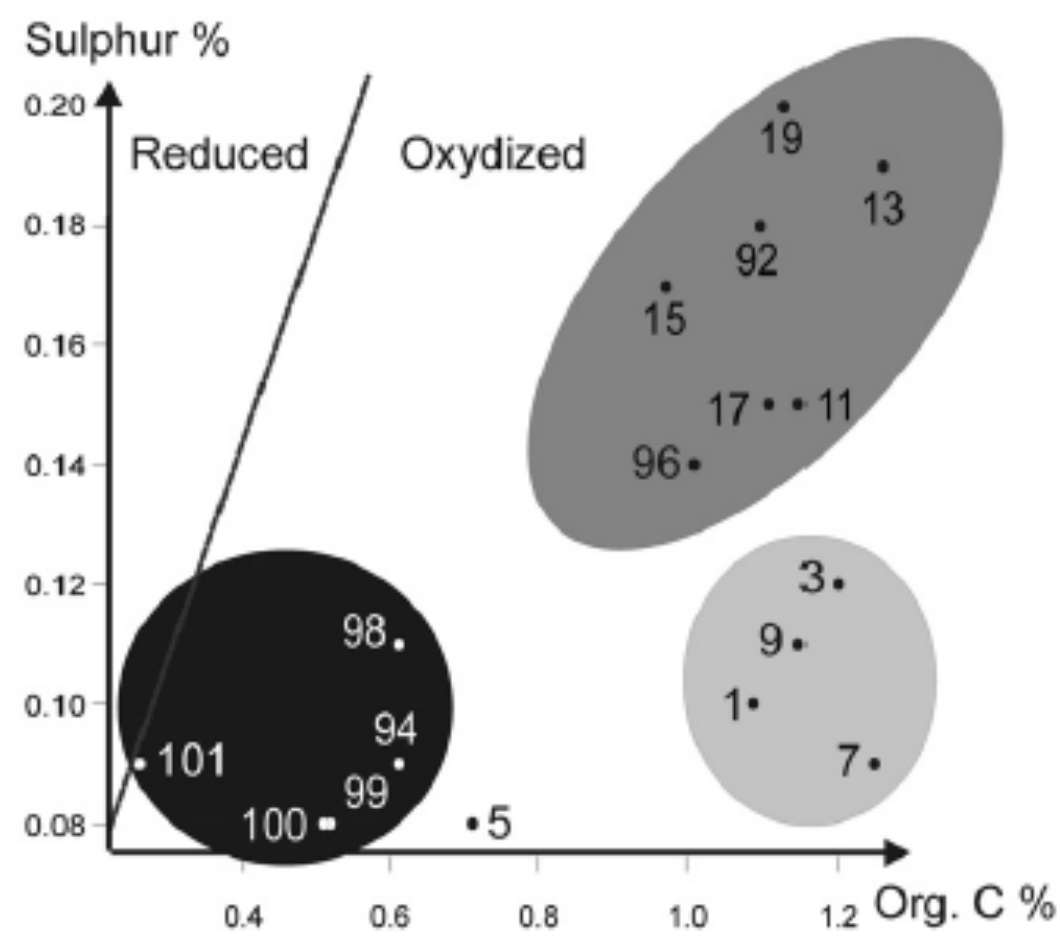

Fig. 4. Distribution of the sediment according to org. C and sulphur proportions, both in wt.\% of dry sediment. The normal marine curve is shown (slope 0.36) (Berner and Raiswell, 1984). 

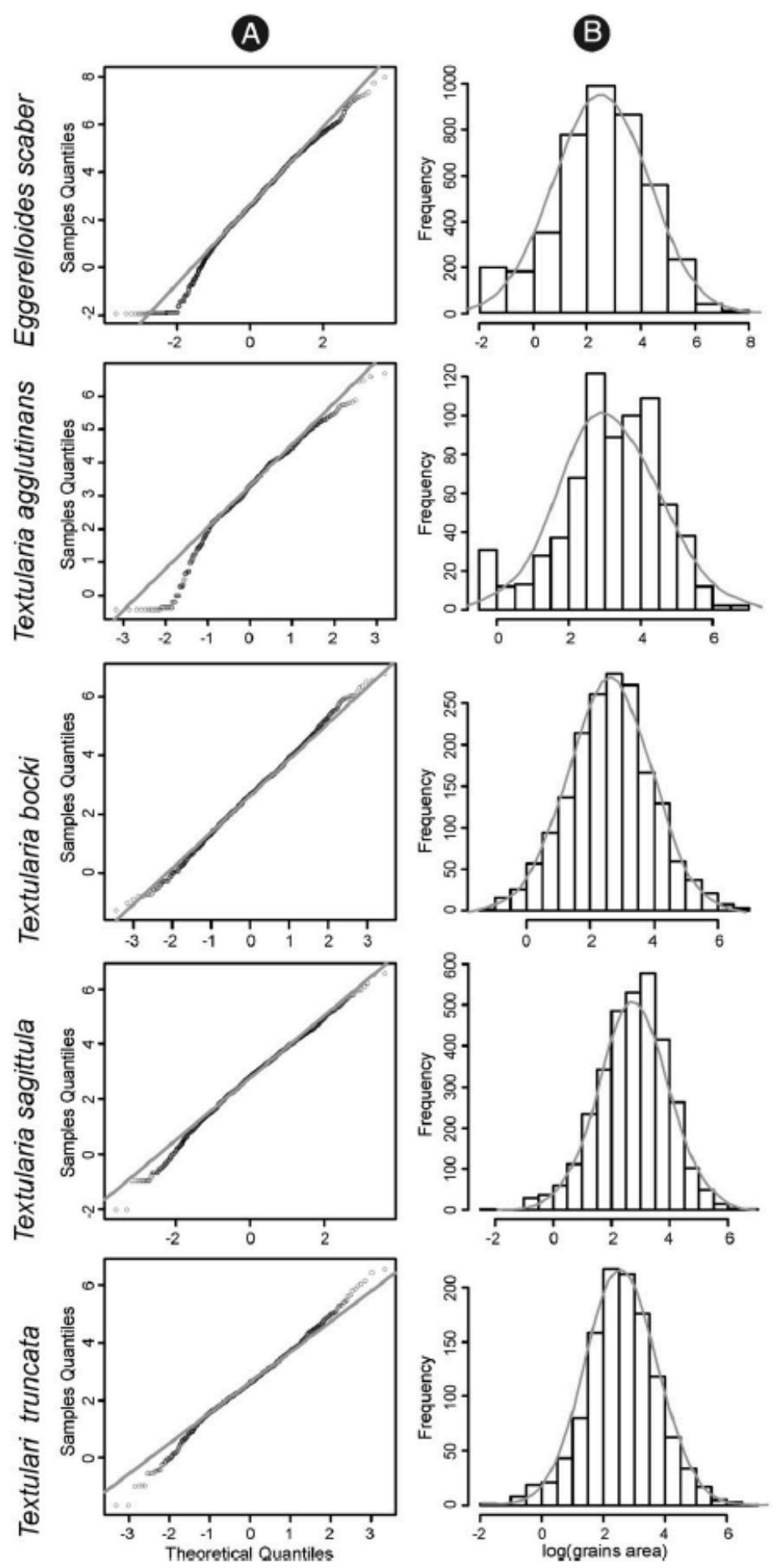

Fig. 5. Grain size distribution by species. A) Normal quantile-quantile plot with the line adjusted upon the first and third quartiles; B) distribution of surface of grains (log). Lognormal curve is superimposed. 


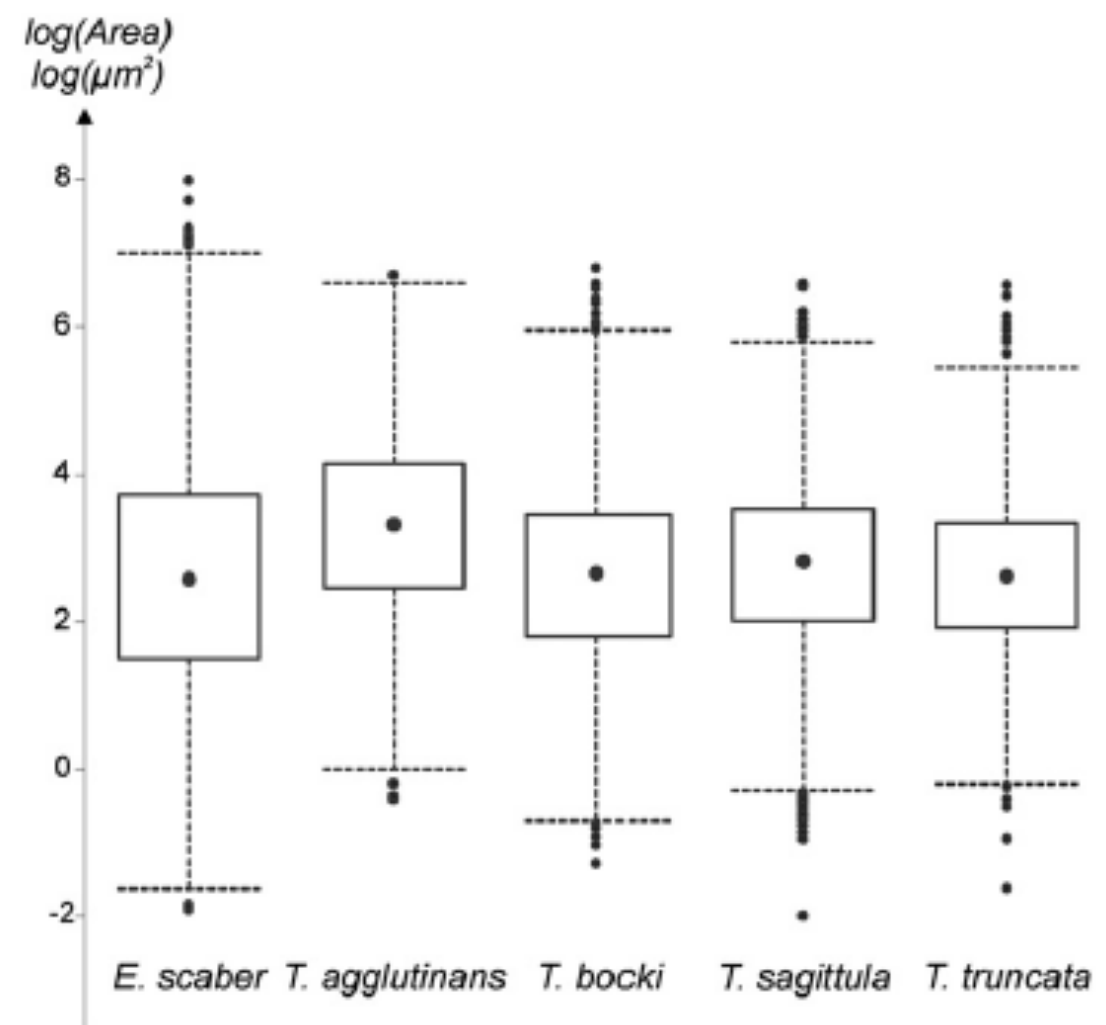

Fig. 6. Box and whisker plot for the distribution of the grain surface within species. 

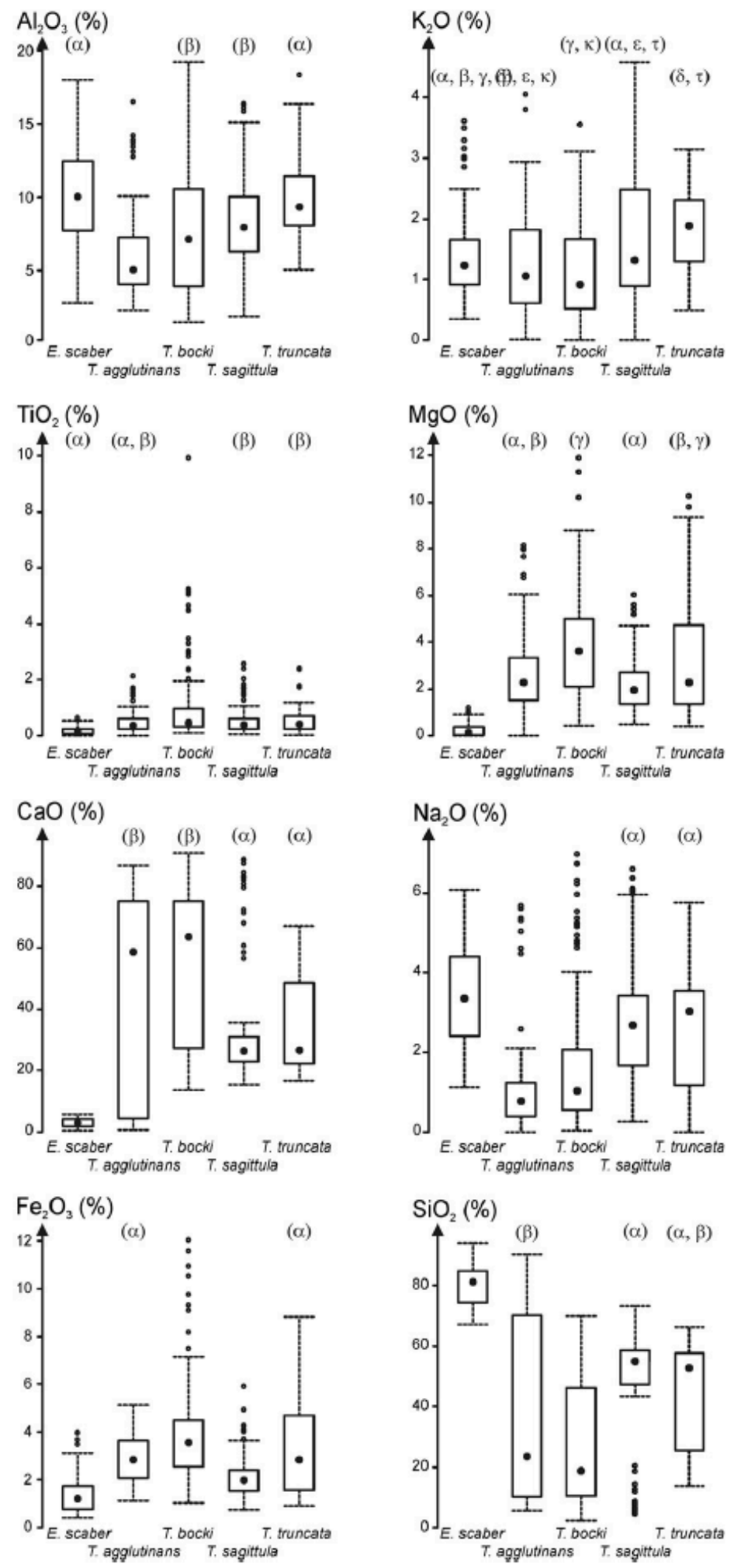

Fig. 7. Box and whisker plot for chemistry of the foraminiferal agglutinated shell. Oxide proportions are given for $\mathrm{Al}_{2} \mathrm{O}_{3}, \mathrm{CaO}, \mathrm{Fe}_{2} \mathrm{O}_{3}, \mathrm{~K}_{2} \mathrm{O}, \mathrm{MgO}, \mathrm{Na}_{2} \mathrm{O}, \mathrm{SiO}_{2}$ and $\mathrm{TiO}_{2}$. Significantly similar distribution of the bulk oxide proportions are indicated by identical Greek letters (Tukey multiple comparisons of means with adjusted $\mathrm{p}>5 \%$ ). Numbers of used specimens are: E. scaber 22, T. sagittula 30, T. agglutinans 24, T. bocki 26, T. truncata 20. 



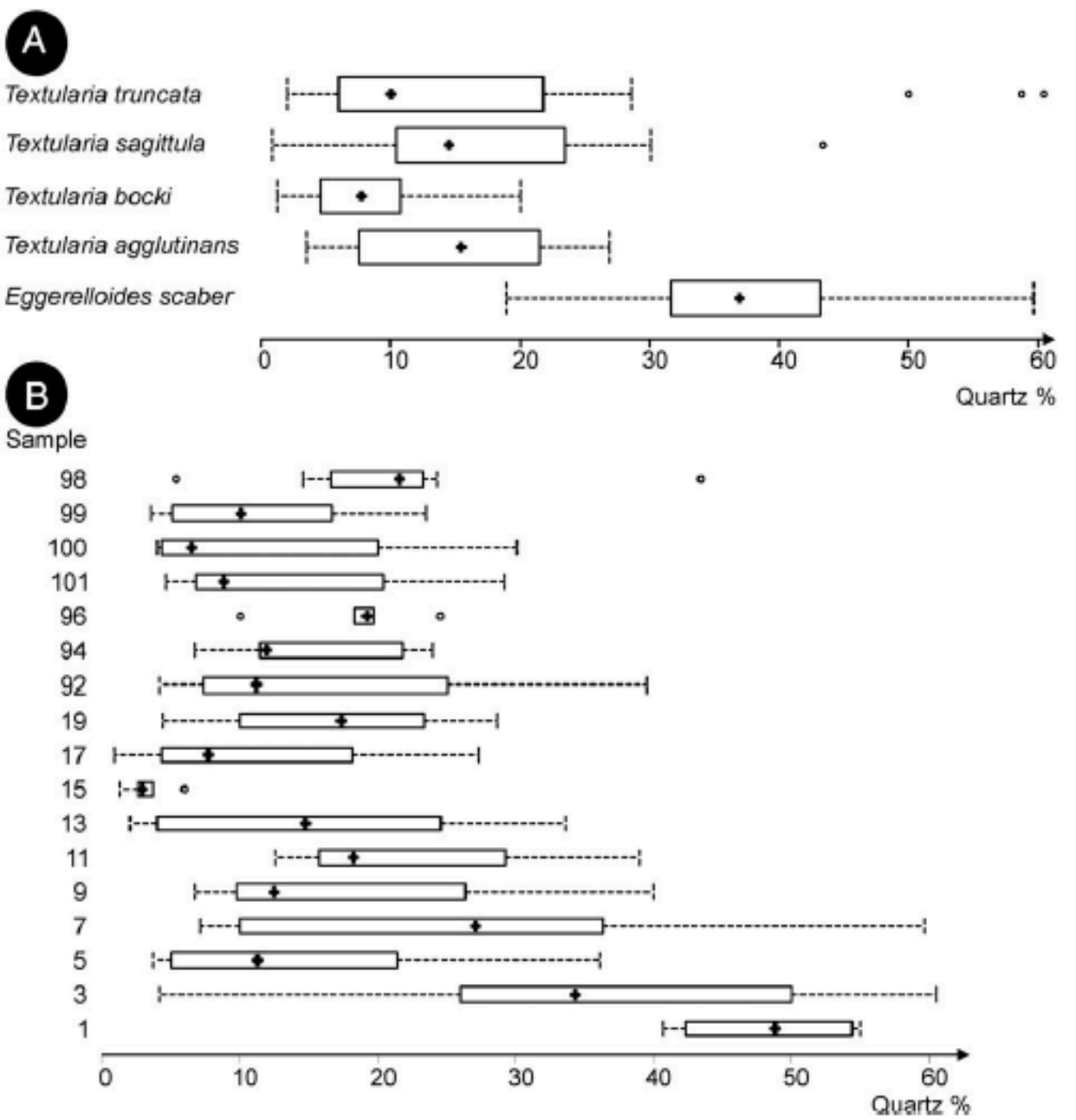

Fig. 8. Box and whisker plot for proportion of quartz agglutinated in shells A) per species, B) per sample. Samples are classified according to increasing water depth from sample 1 to sample 98 . 


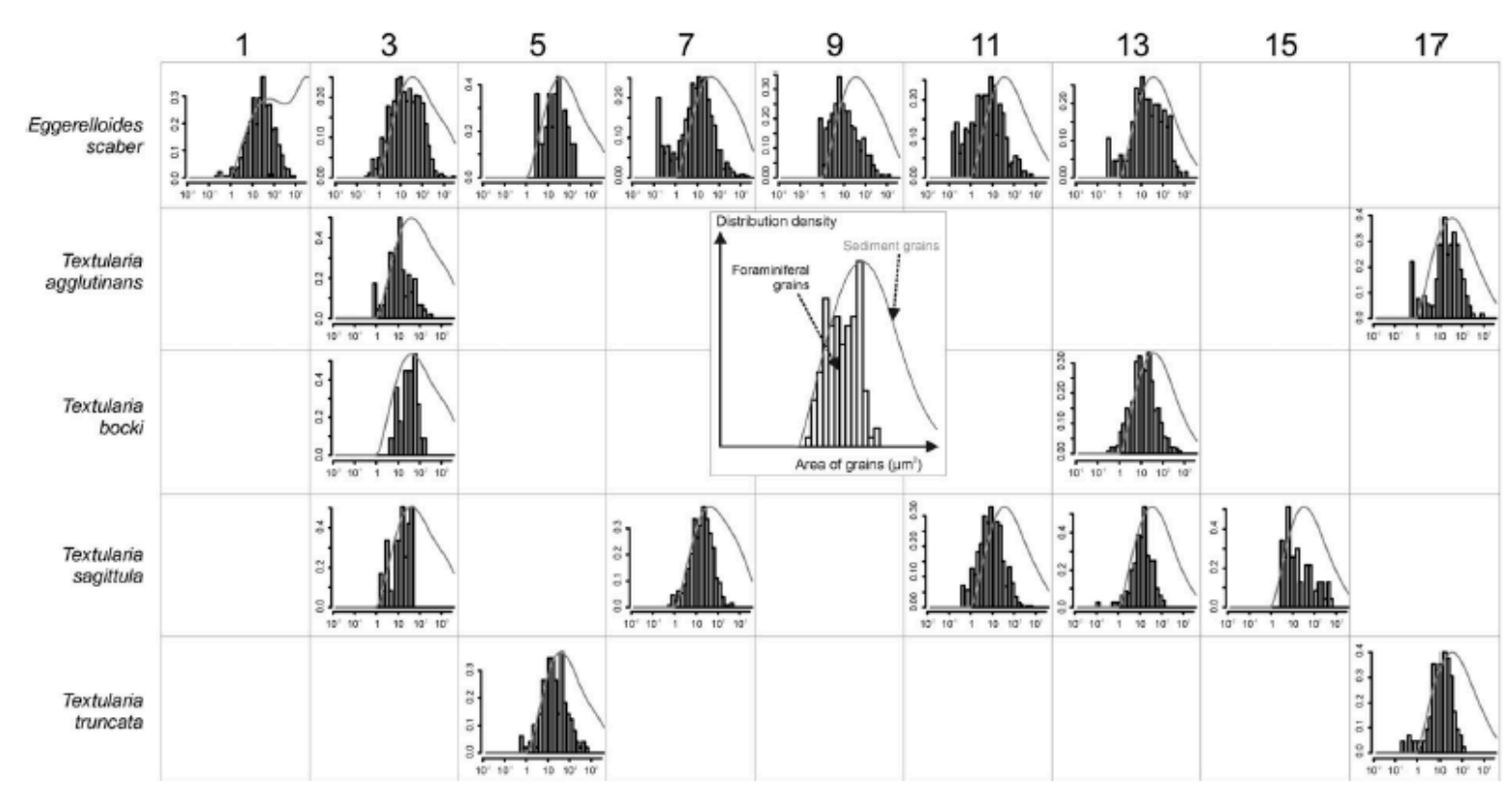

Fig. 9. Comparison between sediment grain size (expressed as surface) distribution and size of the grains agglutinated in the shell of the foraminifera. 


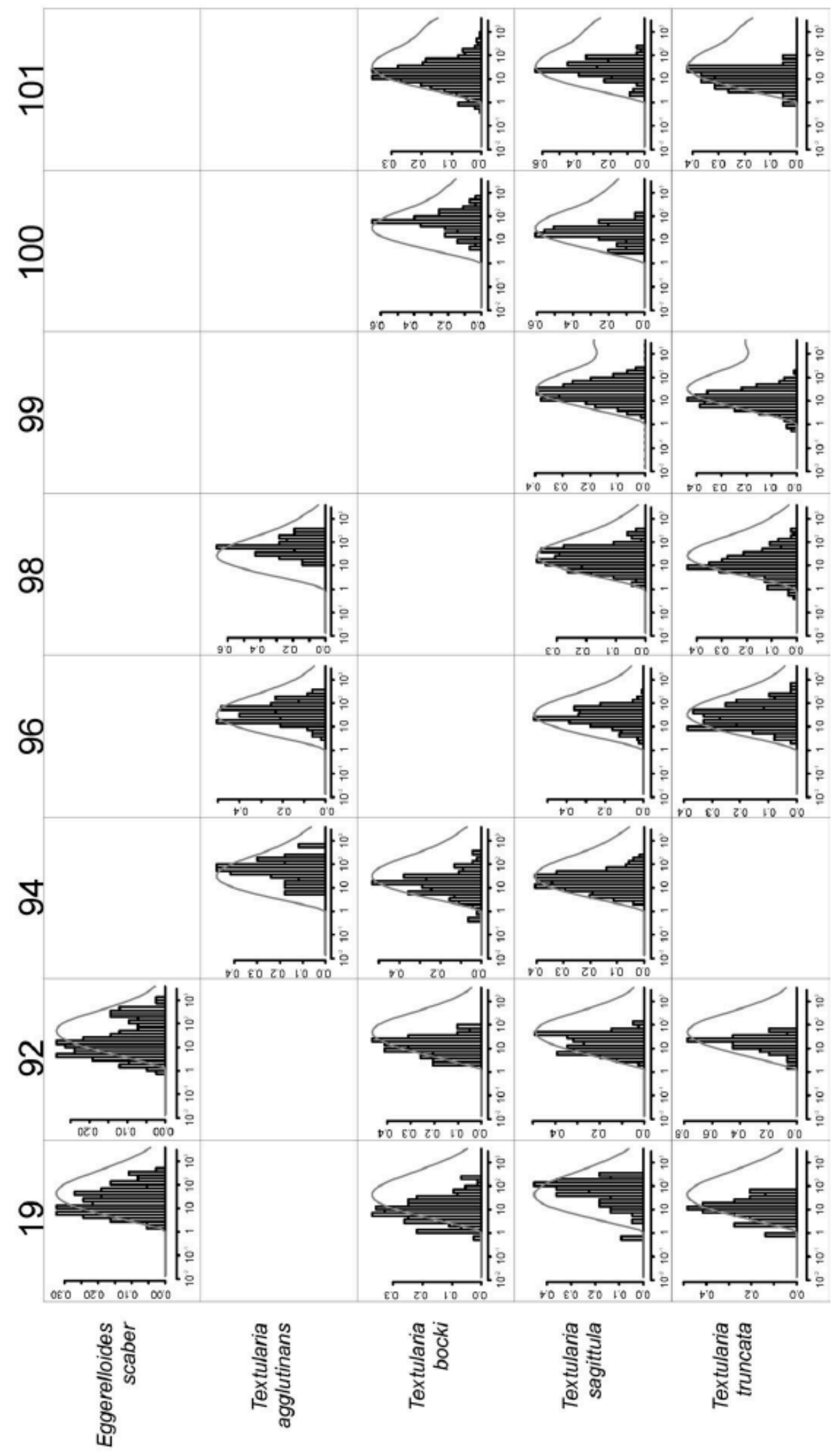

Fig. 9 (continued). 



\section{Table 1}

Clay mineral composition of the sediment. Results are given in percentage of smectite, illite, chlorite and kaolinite.

\begin{tabular}{lllcc}
\hline Sample & Smectite & Illite & Chlorite & Kaolinite \\
\hline 1 & 62 & 13 & 8 & 17 \\
3 & 69 & 13 & 7 & 12 \\
5 & 68 & 14 & 6 & 12 \\
7 & 66 & 15 & 7 & 13 \\
9 & 56 & 19 & 10 & 15 \\
11 & 67 & 18 & 6 & 9 \\
13 & 65 & 19 & 7 & 9 \\
15 & 72 & 15 & 6 & 8 \\
17 & 68 & 18 & 6 & 8 \\
19 & 60 & 22 & 8 & 10 \\
92 & 59 & 23 & 8 & 9 \\
94 & 58 & 24 & 8 & 9 \\
96 & 61 & 23 & 8 & 8 \\
98 & 57 & 25 & 10 & 9 \\
99 & 61 & 22 & 9 & 8 \\
100 & 54 & 24 & 11 & 70 \\
101 & 63 & 21 & 9 & 7 \\
\hline
\end{tabular}

\section{Table 2}

Depth of the samples, proportions of $\mathrm{CaCO}_{3}$, and organic geochemistry $(\mathrm{N}, \mathrm{S}, \mathrm{TC}, \mathrm{Cmin}$, Corg and ratio $\mathrm{C} / \mathrm{N})$.

\begin{tabular}{llclllllr}
\hline Sample & $\begin{array}{l}\text { Depth } \\
(\mathrm{m})\end{array}$ & $\begin{array}{l}\mathrm{CaCO}_{3} \\
(\%)\end{array}$ & $\begin{array}{l}\mathrm{N} \\
(\%)\end{array}$ & $\begin{array}{l}\text { S } \\
(\%)\end{array}$ & $\begin{array}{l}\text { TC } \\
(\%)\end{array}$ & $\begin{array}{l}\text { Cmin } \\
(\%)\end{array}$ & $\begin{array}{l}\text { Corg } \\
(\%)\end{array}$ & Corg/Ntot \\
\hline 1 & 15 & 2 & 0.09 & 0.10 & 1.36 & 0.27 & 1.09 & 11.96 \\
3 & 25 & 5 & 0.12 & 0.12 & 1.82 & 0.62 & 1.20 & 10.29 \\
5 & 35 & 13 & 0.12 & 0.08 & 2.25 & 1.54 & 0.71 & 6.19 \\
7 & 44 & 6 & 0.12 & 0.09 & 2.02 & 0.76 & 1.25 & 10.61 \\
9 & 55 & 8 & 0.12 & 0.11 & 2.13 & 0.98 & 1.15 & 9.54 \\
11 & 65 & 9 & 0.12 & 0.15 & 2.19 & 1.04 & 1.15 & 9.60 \\
13 & 75 & 9 & 0.12 & 0.19 & 2.34 & 1.07 & 1.26 & 10.14 \\
15 & 85 & 9 & 0.10 & 0.17 & 2.05 & 1.08 & 0.97 & 9.69 \\
17 & 105 & 10 & 0.11 & 0.15 & 2.29 & 1.18 & 1.11 & 9.70 \\
19 & 120 & 11 & 0.12 & 0.20 & 2.43 & 1.30 & 1.13 & 9.06 \\
92 & 140 & 11 & 0.12 & 0.18 & 2.37 & 1.27 & 1.10 & 9.38 \\
94 & 175 & 15 & 0.08 & 0.09 & 2.37 & 1.76 & 0.61 & 8.12 \\
96 & 225 & 12 & 0.11 & 0.14 & 2.46 & 1.45 & 1.01 & 9.27 \\
98 & 350 & 11 & 0.08 & 0.11 & 1.97 & 1.35 & 0.61 & 7.90 \\
99 & 325 & 10 & 0.05 & 0.08 & 1.76 & 1.24 & 0.52 & 10.54 \\
100 & 300 & 15 & 0.06 & 0.08 & 2.32 & 1.81 & 0.51 & 8.12 \\
101 & 275 & 14 & 0.05 & 0.09 & 1.88 & 1.62 & 0.26 & 5.54 \\
\hline
\end{tabular}


Table 3

Inorganic geochemistry: (1) Major element composition of the sediment. Proportions are expressed as oxide weight percents. (2) Trace element $(\mathrm{Cu}, \mathrm{Mn}, \mathrm{Ni}, \mathrm{V}, \mathrm{Mo}, \mathrm{U})$ contents of the sediment. Concentrations are expressed in $\mu \mathrm{g} / \mathrm{g}$ (or ppm). When BD (standing for below detection) is noted for Mo, values are below the detection threshold of $1.6 \mu \mathrm{g} / \mathrm{g}$. For each analysed trace element, enrichment factors (EF) are given.

\begin{tabular}{|c|c|c|c|c|c|c|c|c|c|c|c|c|c|c|c|c|c|c|c|c|c|c|c|c|}
\hline \multirow[b]{2}{*}{ Sample } & \multicolumn{12}{|c|}{ Major elements } & \multicolumn{12}{|c|}{ Trace elements } \\
\hline & $\overline{\mathrm{SO}_{2}}$ & $\mathrm{Al}_{2} \mathrm{O}_{3}$ & $\mathrm{Fe}_{2} \mathrm{O}_{3}$ & $\mathrm{MnO}$ & $\mathrm{MgO}$ & $\mathrm{CaO}$ & $\mathrm{Na}_{2} \mathrm{O}$ & $\mathrm{K}_{2} \mathrm{O}$ & $\mathrm{TiO}_{2}$ & $\mathrm{P}_{2} \mathrm{O}_{5}$ & $\begin{array}{l}\text { Loss on } \\
\text { ignition }\end{array}$ & Total & $\mathrm{Cu}$ & $\mathrm{Mn}$ & $\mathrm{Ni}$ & $\mathrm{v}$ & Mo & $\mathrm{U}$ & $\mathrm{EF}_{\mathrm{Ou}}$ & $\mathrm{EF}_{\mathrm{Ma}}$ & $\mathrm{EF}_{\mathrm{Ni}}$ & $\mathrm{EF}_{\mathrm{v}}$ & $\mathrm{EF}_{\mathrm{MO}_{\mathrm{O}}}$ & $\mathrm{EF}_{\mathrm{u}}$ \\
\hline 1 & 55.53 & 15.68 & 7.25 & 0.07 & 2.75 & 2.51 & 2.46 & 2.33 & 1.02 & 0.16 & 10.85 & 100.61 & 59.1 & 611.0 & 77.1 & 150.5 & 1.9 & 3.6 & 2.30 & 0.67 & 1.7 & 1.36 & 1.23 & 1.45 \\
\hline 3 & 49.44 & 16.38 & 7.47 & 0.06 & 2.96 & 3.81 & 2.66 & 2.33 & 0.96 & 0.16 & 14.15 & 100.38 & 66.7 & 484.3 & 86.9 & 156.3 & 1.9 & 4.5 & 2,48 & 1.18 & 1.8 & 1.36 & 1.17 & 1.73 \\
\hline 5 & 49.05 & 14.16 & 6.33 & 0.07 & 2.55 & 7.39 & 2.39 & 2.39 & 0.77 & 0.16 & 15.28 & 100.54 & 45.3 & 504.0 & 67.8 & 120.0 & BD & 3.0 & 1.95 & 0.67 & 1.6 & 1.20 & - & 1.34 \\
\hline 7 & 48.39 & 15.41 & 7.13 & 0.07 & 3.03 & 4.61 & 2.5 & 2.58 & 0.85 & 0.17 & 15.04 & 99.78 & 57.0 & 542.2 & 83.5 & 135.6 & $\mathrm{BD}$ & 3.3 & 2.26 & 0.55 & 1.9 & 1.25 & - & 1.36 \\
\hline 9 & 47.23 & 15.6 & 7.23 & 0.12 & 3.22 & 5.14 & 2.68 & 2.47 & 0.79 & 0.18 & 16.14 & 100.8 & 63.6 & 964,4 & 101.5 & 135.9 & 1.6 & 3.3 & 2.49 & 1.12 & 2.2 & 1.24 & 1.07 & 1.34 \\
\hline 11 & 45.6 & 14.86 & 6.88 & 0.12 & 3.32 & 5.69 & 2.8 & 2.47 & 0.73 & 0.17 & 16.68 & 99.32 & 65.5 & 914.2 & 109.3 & 130.8 & $\mathrm{BD}$ & 3.0 & 2.69 & 0.84 & 25 & 1.25 & - & 1.28 \\
\hline 13 & 44.69 & 14.66 & 6.73 & 0.09 & 3.41 & 5.95 & 3.07 & 2.43 & 0.71 & 0.19 & 17.61 & 99.54 & 70.9 & 703.2 & 117.6 & 137.3 & BD & 3.3 & 2.95 & 0.74 & 2.8 & 1.33 & - & 1.42 \\
\hline 15 & 46.61 & 15.2 & 6.94 & 0.08 & 3.55 & 5.41 & 2.75 & 2.58 & 0.73 & 0.18 & 16.31 & 100.34 & 65.5 & 664.2 & 124.6 & 139.8 & BD & 3.7 & 2.63 & 0.71 & 28 & 1.31 & - & 1.55 \\
\hline 17 & 45.69 & 14.74 & 6.73 & 0.08 & 3.49 & 6.15 & 2.67 & 2.51 & 0.71 & 0.15 & 16.92 & 99.84 & 61.6 & 639.5 & 126,4 & 137.3 & $\mathrm{BD}$ & 1.9 & 2.55 & 0.56 & 2.9 & 1.32 & - & 0.82 \\
\hline 19 & 44.86 & 14.4 & 6.74 & 0.12 & 3.49 & 6.41 & 2.9 & 2.45 & 0.69 & 0.16 & 17.72 & 99.94 & 54.6 & 944.5 & 122.2 & 133.1 & BD & 1.3 & 2.31 & 0.92 & 2.9 & 1.31 & - & 0.58 \\
\hline 92 & 43.63 & 14.14 & 6.63 & 0.08 & 3.7 & 6.89 & 3.74 & 2.42 & 0.69 & 0.13 & 18.82 & 100.87 & 60.3 & 602.0 & 121.5 & 126.4 & BD & 1.5 & 2.60 & 0.66 & 3.0 & 1.27 & - & 0.66 \\
\hline 94 & 53.48 & 11.07 & 4.96 & 0.11 & 2.76 & 8.3 & 2.05 & 2.11 & 0.5 & 0.12 & 14.72 & 100.18 & 53.7 & 1001.5 & 110.7 & 97.3 & BD & 1.0 & 2.95 & 1.58 & 3.4 & 1.25 & - & 0.56 \\
\hline 96 & 44.57 & 14.34 & 6.65 & 0.08 & 3.65 & 7.25 & 2.7 & 2.46 & 0.69 & 0.15 & 17.66 & 100.2 & 58.8 & 667.1 & 129.8 & 131.0 & BD & 1.3 & 2.50 & 2.57 & 3.1 & 1.30 & - & 0.57 \\
\hline 98 & 50.49 & 13.36 & 5.72 & 0.07 & 3.33 & 7.02 & 2.63 & 2.44 & 0.59 & 0.13 & 14.7 & 100.48 & 48.0 & 528.0 & 125.1 & 119.2 & BD & 0.9 & 2,19 & 1.73 & 3.2 & 1.27 & - & 0.40 \\
\hline 99 & 58.21 & 11.02 & 4.65 & 0.06 & 2.73 & 6.84 & 2.34 & 2.1 & 0.53 & 0.12 & 11.33 & 99.93 & 39.7 & 547.5 & 130.9 & 92,3 & BD & 1.1 & 2.20 & 1.36 & 4.1 & 1.19 & - & 0.61 \\
\hline 100 & 54.03 & 10.92 & 4.8 & 0.09 & 2.74 & 9.41 & 2.06 & 2.11 & 0.5 & 0.12 & 13.81 & 100.59 & 47.7 & 646.5 & 106.5 & 92.5 & BD & 0.7 & 2.66 & 2.15 & 3.4 & 1.20 & - & 0.39 \\
\hline 101 & 57.71 & 11.51 & 4.64 & 0.08 & 2.4 & 7.56 & 2.07 & 2.91 & 0.51 & 0.16 & 11.06 & 100.61 & 38.7 & 704.3 & 104.2 & 87.2 & $\mathrm{BD}$ & 1.0 & 2.05 & 2.62 & 3.1 & 1.08 & - & 0.56 \\
\hline
\end{tabular}

\section{Table 4}

Shapiro-Wilk test of normality of the $\log$ of the distribution for grains size (Surface) agglutinated on foraminiferal: (1) pooled by foraminiferal species, (2) pooled by sample. Wis the value of the Shapiro-Wilk statistic associated to a p-value. Log-normality is rejected when p-value b0.05. Data are analysed separately then in the case (1) are analysed grouped by class using Sturges rule.

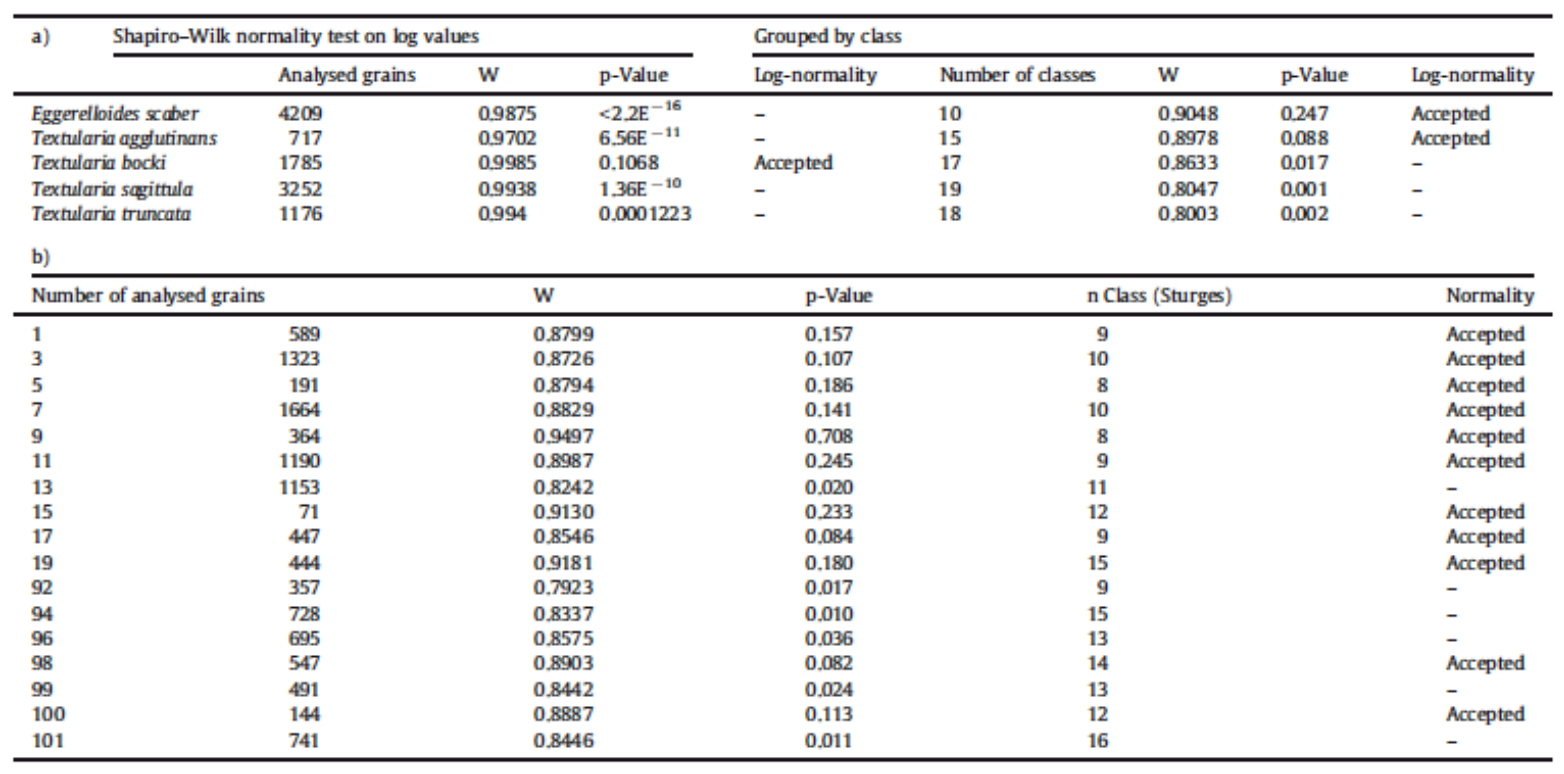




\section{Table 5}

Comparison between the mean grain sizes of the 5 species using Tukey's 'Honestly Significant Difference' method. The intervals are based on the Studentized range statistic. Diff is the difference in the observed means, lwr is the lower end point of the interval, upr is the upper end point and $\mathrm{p}$ adj is the p-value after adjustment for the multiple comparisons. When $\mathrm{p}$ adj is $>0.05$ (marked by $*$ ), the shells of a given species could be considered as constructed with homogenous mean grain size.

\begin{tabular}{|c|c|c|c|c|}
\hline & diff & lwr & upr & $\mathrm{p}$ adj \\
\hline T. sagit tula-E, scaber & -19.26 & -37.57 & -0.95 & 0.03 \\
\hline T. agghutinans-E, scaber & -0.51 & -24.46 & 23.44 & 1.00 \\
\hline T, bocki-E, scaber & -17.48 & -41.43 & 6.47 & 0.26 \\
\hline T. truncata-E, scaber & -23.09 & -44.76 & -1.43 & 0.03 \\
\hline T. agghut in ans- $T$, sagit tula & 18.75 & -5.66 & 43.16 & 0.21 \\
\hline T. bocki- $T$, sagittula & 1.78 & -22.63 & 26.19 & 1.00 \\
\hline T. truncata- $T$, sqgittula & -3.83 & -26.01 & 18,34 & 0.99 \\
\hline$T$, bocki- $T$, agghutinans & -16.97 & -45.85 & 11.92 & 0.47 \\
\hline T. tnencata-T, agglutinans & -22.58 & -49.60 & 4.44 & 0.14 \\
\hline T. tnencata-T. bocki & -5.61 & -32.63 & 21.41 & 0.98 \\
\hline
\end{tabular}


Table 6

Statistical investigation on quartz distribution on the shells: (a) Analysis of the influence of quartz proportion on sample and on species. Results of ANOVA are given as: Df, Sum Sq, Mean Sq, as well as $\mathrm{F}$ value and $\operatorname{Pr}(>\mathrm{F})$. Only if $\operatorname{Pr}(>\mathrm{F})$ was $>5 \%$ variance model should be accepted. (b) Comparison investigation between the quartz proportions of the five species, using the Tukey's 'Honest Significant Difference' method. The intervals are based on the Studentized range statistic. diff is the difference in the observed means, lwr is the lower end point of the interval, upr is the upper end point and $\mathrm{p}$ adj is the $\mathrm{p}$-value after adjustment for the multiple comparisons. When $\mathrm{p}$ adj. are $>0.05$ (marked with $*$ ), mean quartz proportion per species could be considered as similar. (c) Comparison between the quartz proportions within shells of the 17 samples, using Tukey's Honest Significant Difference' method. The p-value after adjustment for the multiple comparisons is given. When p-adj. are $>0.05$ (cells in grey), mean quartz proportion per sample could be considered as similar.

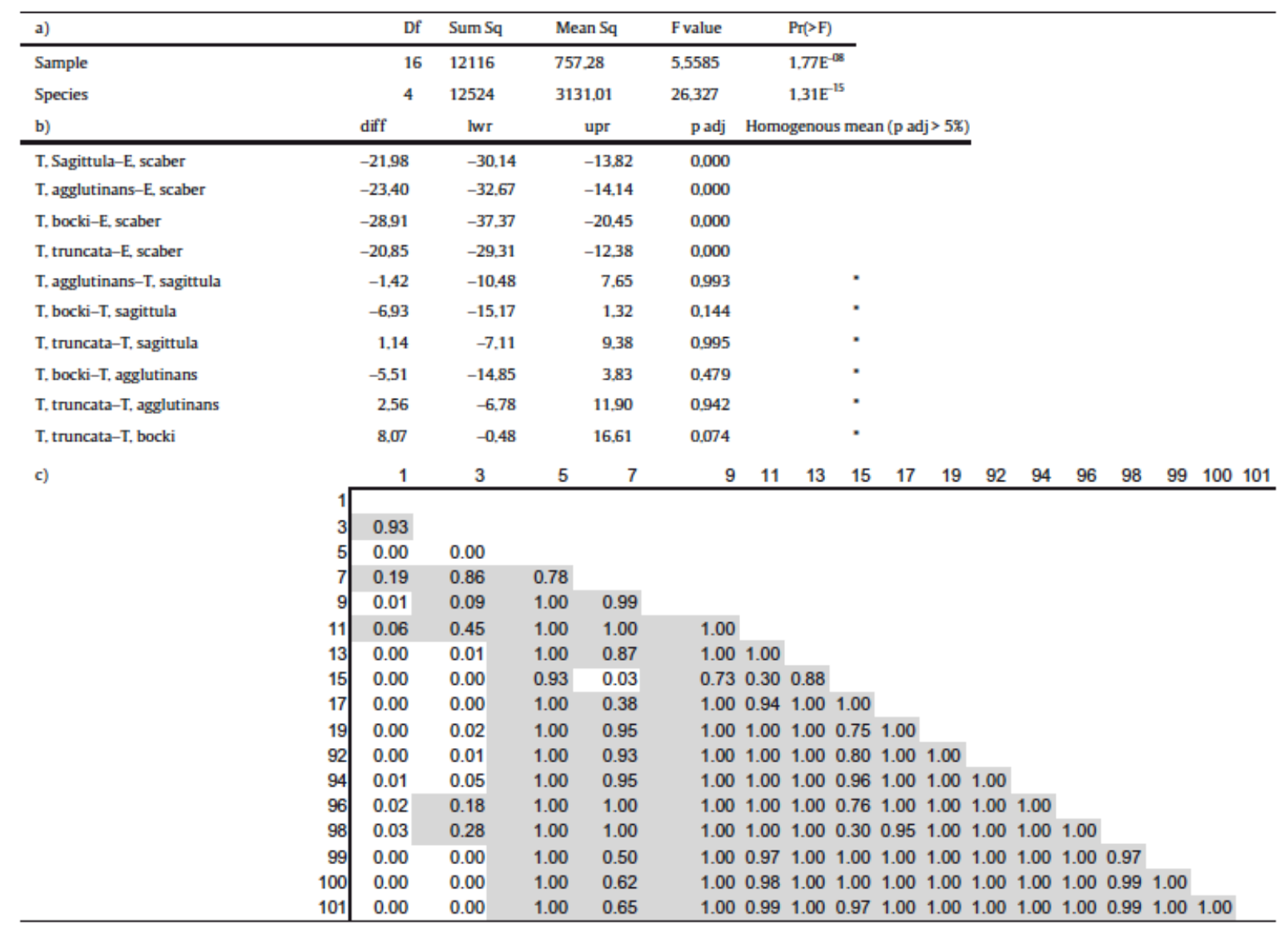

